Research Article

\title{
Evaluating the Energy Efficiency of PCM-Integrated Lightweight Steel-Framed Building in Eight Different Cities of Warm Summer Humid Continental Climate
}

\author{
Baurzhan Jangeldinov (D), Shazim Ali Memon (D), Jong Kim (D), \\ and Marzhan Kabdrakhmanova \\ Department of Civil Engineering, Nazarbayev University, Nur-Sultan 010000, Kazakhstan \\ Correspondence should be addressed to Shazim Ali Memon; shazim.memon@nu.edu.kz
}

Received 29 August 2019; Revised 1 February 2020; Accepted 15 February 2020; Published 16 March 2020

Academic Editor: Dora Foti

Copyright ( $(2020$ Baurzhan Jangeldinov et al. This is an open access article distributed under the Creative Commons Attribution License, which permits unrestricted use, distribution, and reproduction in any medium, provided the original work is properly cited.

\begin{abstract}
Phase change materials have been applied to a building framework to decrease energy and fossil fuel consumption as well as make the building sector more sustainable. Lightweight structures are attractive and increasingly being used in residential buildings. Hence, in this research, the energy efficiency and thermal performance of buildings located in eight various cities (Helsinki, Kiev, Saint Petersburg, Moscow, Stockholm, Toronto, Montreal, and Kiev) of warm summer humid continental climate (Dfb) were evaluated. The impact of heating and cooling energy savings pattern on the selection of optimum phase change material for each city has been demonstrated. In addition, the impact of volume of PCM, precisely the effect of varying and constant volume, on energy savings was assessed for the lightweight steel-framed building. Simulations were performed in EnergyPlus by applying eleven melting temperature ranges of PCM. Test results demonstrated that energy savings were higher in the swing season and the maximum temperature reduced during these months was $3.3^{\circ} \mathrm{C}$. Heating and cooling energy savings were found to strongly influence the selection of optimum PCM. In cities where cooling energy savings were the highest, the optimum PCMs were PCMs 24-26 while in cities where heating energy savings were the highest, the optimum PCM was found to be PCM 21. For constant volume, the performance of optimum PCM raised when the surface area was enlarged, while the thickness of PCM was reduced. Overall, the application of PCM into lightweight steel-framed residential structure located in warm summer humid continental climate region is a feasible option.
\end{abstract}

\section{Introduction}

The energy utilization in building sector possesses a crucial impact on total energy consumption. According to the International Energy Agency, the space heating and cooling energy in buildings comprise up to $50 \%$ in a cold climate region [1]. In addition, climate change is occurring due to global warming. Nowadays, about $80 \%$ of the energy is produced by fossil fuel, which contributes to environmental pollution such as emission of harmful gases into the environment [2]. Environmental pollution, in turn, has a negative impact on human health. According to the predictions, without any improvements in energy efficiency systems, the worldwide energy demand will rise by up to $50 \%$ in 2050 [3].

The enhancement of the building framework according to thermal comfort is regarded as a proper solution to diminish the heating and cooling energy demands $[4,5]$. The energy efficiency of structure can be enhanced by using either active [6] or passive thermal energy storage systems [7]. However, the passive system can provide high-energy efficiency by the sun as a clean and renewable energy source [8] and is a crucial part of the sustainable approach in building industry. One of the methods is to use latent thermal energy storage systems into building envelopes to provide a balance between diurnal and nocturnal energy consumption $[9,10]$. Phase change 
materials (PCMs) are materials which can absorb a great amount of energy by means of latent heat when they experience a change in the physical state (from liquid to solid and vice versa); thus they are used to minimize energy consumption in buildings $[11,12]$.

Many researchers have used building simulation tools, which provide time and cost-efficient solution, to assess the energy efficiency and thermal performance in PCM incorporated buildings [13-15]. Vautherot et al. [16] analyzed the effect of varying heating setpoint and phase change temperature on energy savings and thermal comfort enhancement. For a two-storey residential structure located in Auckland, the authors by using an appropriate scenario in EnergyPlus found considerable energy savings and up to $31 \%$ fewer discomfort hours. Pajek et al. [17] assessed the thermal performance of lightweight timber building with different wall systems in three different European cities (Helsinki, Vienna, and Madrid). The authors found that enhanced lightweight buildings performed better in northern and central European locations. Mi et al. [18] evaluated the implementation of PCM 27 incorporated into three-storey office building situated in different cities of China and found that the efficiency of PCM impregnated building was superior in the city of Shenyang, Zhengzhou, and Changsha. Ramakrishnan et al. [19] used a discomfort index to examine the possibility of decreasing heat stress risks during extreme heatwave event in Melbourne, Australia. The authors reported that by using better ventilation design and PCM 29, the discomfort period during extreme heatwave conditions reduced by $65 \%$. Ascione et al. [20] evaluated the energy refurbishment in an office building in five different cities (Ankara, Athens, Naples, Marseille, and Seville) having a Mediterranean climate. The authors revealed that the greatest cooling energy savings were obtained when PCM plaster having a thickness of $3 \mathrm{~cm}$ was applied on all vertical exposures of the building. Soares et al. [21] applied multidimensional optimization technique to assess the energy saving potential of PCM-integrated lightweight steel-framed residential room in two major climate zones (warm temperate (C) and snow (D)). The authors suggested that heating and cooling energy savings were higher in warmer climates, for example, $46 \%$ in Seville (Csa) and 62\% in Coimbra (Csb). Marin et al. [9] analyzed the energy saving potential of the lightweight single-zone relocatable building impregnated with phase change materials in various climate zones. The outcomes of this study demonstrated that PCM-enhanced relocatable buildings performed better in warm and arid temperate climates, whereas the output for tropical and snow climates was limited. Saffari et al. [8] utilized a single-objective optimization technique to find optimum PCMs (from PCM 20 to PCM 26) in various climate zones. The authors revealed that for the heating predominant climate the phase change material with low melting temperature (PCM 20) performed superior while in cooling predominant climate, the performance of high melting point PCM (PCM 26) was more efficient.

Lightweight structures are attractive and increasingly being used in residential buildings [17, 21, 22]. Therefore, we are going to evaluate the energy efficiency and thermal performance of PCM impregnated lightweight buildings situated in eight various cities of Dfb climate zone. The impact of heating and cooling energy savings pattern on the selection of optimum phase change material for each city located in a warm summer humid continental climate has been demonstrated. It is also known that energy savings in buildings are dependent on the volume of PCM to be installed (which depends on PCM surface area and thickness of the PCM layer). Hence, we are also going to evaluate the impact of PCM volume (constant and varying volumes) on energy savings for the lightweight steel-framed building located in a warm summer humid continental climate.

\section{Methodology}

2.1. Characterization of the Climate. Based on empirical observations, Koppen developed the first quantitative climate classification system of the world to specify the boundaries of various climate types [23, 24]. The climate characterization system used monthly data of temperature and precipitation to set up boundaries of various climate zones worldwide [23]. In 2006, the updated digitalized version of Köppen-Geiger classification system was presented [24]. In this research, we considered the thermal performance and energy saving potential of the residential structure located in warm summer humid continental climate (Dfb) (Figure 1). Dfb climate is described by long and cool summers, with the average temperatures in the warmest month, July, reaching temperatures above $20^{\circ} \mathrm{C}\left(70^{\circ} \mathrm{F}\right)$. In winter temperature often drops under $-18^{\circ} \mathrm{C}\left(0^{\circ} \mathrm{F}\right)$ for long periods of time. Additionally, the snowfall occurs often and stays on the ground surface for a long time [25]. According to Peel et al. [26], the snow zone D dominates in the territories of Europe (44,4\%) and North America (54.5\%). In total, eight cities (five from Europe and three from North America, as illustrated in Table 1) were analyzed. The cities were selected on the basis of their geographical location and importance in terms of economic development and population. Specifically, the cities were chosen so that the distance between them allows covering the whole climate zone. Table 1 provides geographic details of the selected cities, namely, the position (latitude and longitude) and the elevation.

2.2. EnergyPlus and Details of the PCM Model. The conduction finite difference (CondFD) algorithm, integrated with EnergyPlus, was offered by Pederson [27] and revised by Tabares-Velasco et al. [28]. The model represents an implicit finite difference scheme, which is paired with the enthalpy temperature function to accurately reflect for phase change energy calculations. The implicit formulation for an internal node is described by the following equation:

$$
\begin{aligned}
\rho C_{p} \Delta x \frac{T_{i}^{\text {present }}-T_{i}^{\text {previous }}}{\Delta t}= & k_{\mathrm{int}} \frac{T_{i+1}^{\text {present }}-T_{i}^{\text {present }}}{\Delta x} \\
& +k_{\text {ext }} \frac{T_{i-1}^{\text {present }}-T_{i}^{\text {present }}}{\Delta x}
\end{aligned}
$$




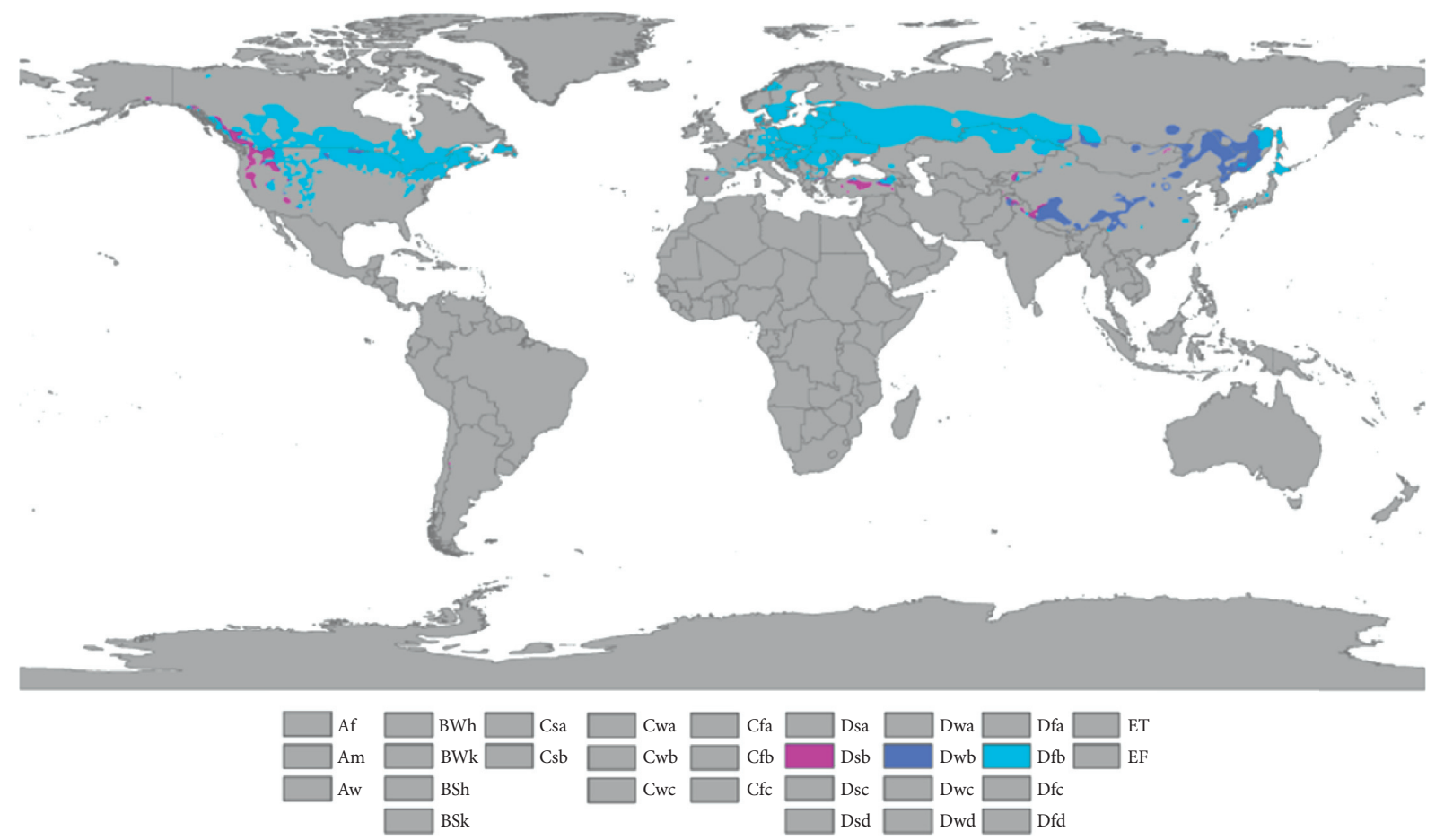

Figure 1: Map of the world according to Köppen-Geiger climate classification (Dfb is in light blue).

Table 1: Details of the selected cities in Dfb climate zone.

\begin{tabular}{|c|c|c|c|c|c|}
\hline Köppen climate & Country & City & Latitude & Longitude & Elevation $(\mathrm{m})$ \\
\hline \multirow{8}{*}{$\mathrm{Dfb}$} & Finland & Helsinki & $60^{\circ} 11^{\prime} \mathrm{N}$ & $24^{\circ} 56^{\prime} \mathrm{E}$ & 56 \\
\hline & Ukraine & Kiev & $50^{\circ} 26^{\prime} \mathrm{N}$ & $30^{\circ} 31^{\prime} \mathrm{E}$ & 182 \\
\hline & Russia & Saint Petersburg & $59^{\circ} 58^{\prime} \mathrm{N}$ & $30^{\circ} 19^{\prime} \mathrm{E}$ & 12 \\
\hline & Russia & Moscow & $55^{\circ} 45^{\prime} \mathrm{N}$ & $37^{\circ} 37^{\prime} \mathrm{E}$ & 151 \\
\hline & Sweden & Stockholm & $59^{\circ} 20^{\prime} \mathrm{N}$ & $18^{\circ} 03^{\prime} \mathrm{E}$ & 14 \\
\hline & Canada & Toronto & $43^{\circ} 38^{\prime} \mathrm{N}$ & $79^{\circ} 24^{\prime} \mathrm{W}$ & 79 \\
\hline & Canada & Montreal & $45^{\circ} 30^{\prime} \mathrm{N}$ & $73^{\circ} 39^{\prime} \mathrm{W}$ & 50 \\
\hline & Canada & Ottawa & $45^{\circ} 25^{\prime} \mathrm{N}$ & $75^{\circ} 41^{\prime} \mathrm{W}$ & 71 \\
\hline
\end{tabular}

where

$$
\begin{aligned}
& k_{\text {int }}=\frac{\left(k_{i+1}^{\text {present }}+k_{i}^{\text {present }}\right)}{2}, \\
& k_{\text {ext }}=\frac{\left(k_{i-1}^{\text {present }}+k_{i}^{\text {present }}\right)}{2} .
\end{aligned}
$$

The subscripts present and previous refer to the present and previous time step, $i$ refers to the node that is being modelled while $i-1$ and $i+1$ represent the nodes that are adjacent to the inner and outer sides of the construction correspondingly, and $\Delta x$ refers to finite difference layer thickness and defines the space between the nodes. All elements are discretized by equation (3) which is influenced by space discretization constant $c$, the thermal diffusivity $\alpha^{*}$, the time step $\Delta t$, and Fourier number $F_{0}$.

$$
\Delta x=\sqrt{c \alpha^{*} \Delta t}=\sqrt{\frac{\alpha^{*} \Delta t}{F_{0}}} .
$$

The enthalpy $(h)$ and thermal conductivity $(k)$ of the PCM are related to the temperature by the following equations:

$$
\begin{aligned}
& h_{i}=h\left(T_{i, j}\right) . \\
& k_{i}=k\left(T_{i, j}\right) .
\end{aligned}
$$

Equation (1) is paired with equations (4) and (5) and the specific heat capacity for the phase change material at each time step is updated by using the following equation:

$$
C_{P}=\frac{h_{i}^{\text {present }}-h_{i}^{\text {previous }}}{T_{i}^{\text {present }}-T_{i}^{\text {previous }}} .
$$

In this research, 11 different PCMs (PCM 18 to PCM 28) having temperature enthalpy curve as illustrated in Figure 2 and latent heat of $219 \mathrm{~kJ} / \mathrm{kg}$ were used. The curves were produced by following the guidelines presented in the research done by Alam et al. [29]. Each PCM has a melting temperature range of $4^{\circ} \mathrm{C}$. For example, PCM 24 has a phase 


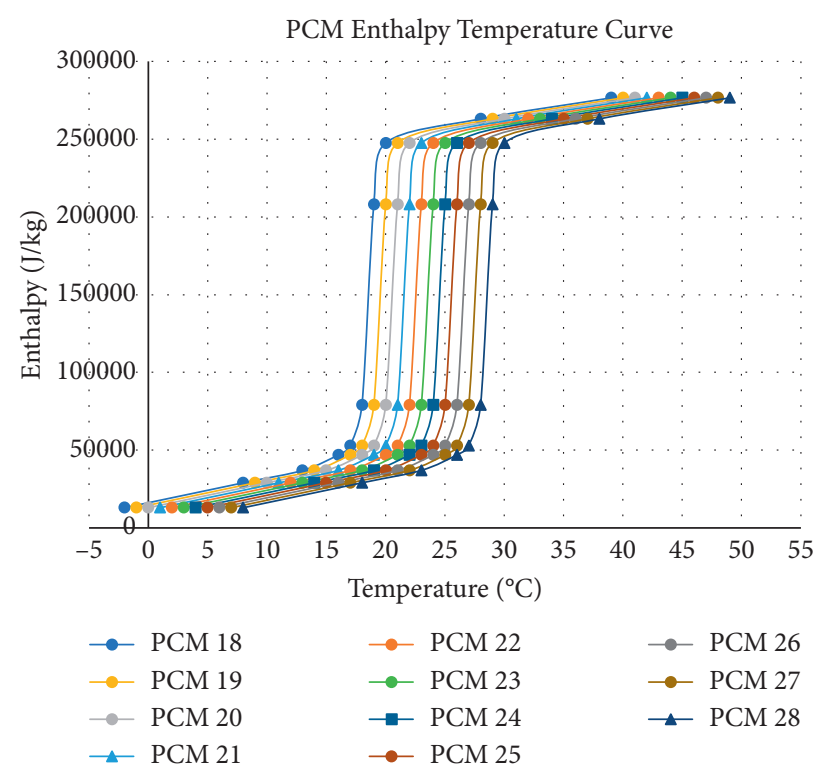

Figure 2: Enthalpy temperature curves for PCMs 18-28.

change cycle from $22^{\circ} \mathrm{C}$ to $26^{\circ} \mathrm{C}$. Thus, the enthalpy temperature curves of PCM are presented in Figure 2.

2.3. Details of Building Envelope. A two-storey low-rise residential building with an inclined pitched roof was used for simulation. The building has a rectangular shape having $12.18 \mathrm{~m}$ width, $9.16 \mathrm{~m}$ length, and $6.55 \mathrm{~m}$ height (Figure 3 ). The windows $(2.1 \mathrm{~m} \times 2.1 \mathrm{~m})$ are assembled at $1 \mathrm{~m}$ above the floor grade while a door $(1.2 \mathrm{~m} \times 2.1 \mathrm{~m})$ is installed on the south side. The lightweight hybrid steel-framed construction mentioned in [21] is applied for the building framework. The properties of an external wall, pitched roof, and ground floor were selected in accordance with Dfb climate region [21]. The thermophysical properties of the external wall, pitched roof, intermediate floor, and slab-on-grade are presented in Figure 4 and Table 2 respectively. It is pertinent to mention here that phase change materials were inserted into the inner sides of the external walls and the roof of the building. Various researchers $[9,21,30]$ have suggested that PCM should be installed at the inner surfaces.

The schedule of HVAC was according to the guidelines of the residential building as given in Saffari et al. [31] (00: 00-8:00 and 16:00-24:00 hrs). According to Werner [32], 51 percent of buildings located in the European Union, Russia, and China use district heating and cooling HVAC system. Hence, for energy analysis, fan coil with district heating and cooling HVAC system was adopted. By following the requirements of the BS standard [33], the thermostat values were set from $20^{\circ} \mathrm{C}$ to $26^{\circ} \mathrm{C}$.

2.4. Validation. In this research, the DesignBuilder model was verified against experimental model [34]. The experiment model with dimensions of $500 \mathrm{~mm} \times 500 \mathrm{~mm} \times 500 \mathrm{~mm}$ was constructed with lightweight aggregate concrete impregnated with PCM layer (Figure 5). The construction details and properties of materials were taken from [34]. The experiment and simulation results of the inside air temperature for a 24-hour period are presented in Figure 6. It is clear that the maximum discrepancy between the simulation and experimental values for indoor air temperature were found to be less than $5.5 \%$. Hence, the developed model can be used for parametric study.

\section{Results and Discussion}

3.1. Monthly Assessment of PCM-Integrated Buildings. This section describes the monthly energy demand for reference building (without PCM) and associated monthly energy savings of the different PCMs, which were incorporated into the reference building. The results of energy savings in residential building incorporated with different PCMs and energy consumption by the residential building (without PCM) in eight different cities of Dfb region are presented in Figure 7. The bars indicate the heating and cooling energy consumption for the residential building without PCM while the lines represent the monthly energy savings obtained when different PCMs in the range from $18^{\circ} \mathrm{C}$ to $28^{\circ} \mathrm{C}$ were incorporated into the residential building. Regarding the $x$-axis, the numbers $1-12$ indicate months, with 1 and 12 representing January and December, respectively.

For a clear understanding, only the results of one city from Europe (Helsinki) and North America (Toronto) would be explained in detail. For Helsinki, no cooling demand was required in January, February, March, November, and December. This is due to the reason that the outside temperature during these months was low: $-3.1^{\circ} \mathrm{C},-4.5^{\circ} \mathrm{C}$, $-1.4^{\circ} \mathrm{C}, 2.6^{\circ} \mathrm{C},-2.1^{\circ} \mathrm{C}$ for January, February, March, November, and December correspondingly. Therefore, the energy was spent only for heating purposes. The heating demand in these months ranged from 448.77 to $867 \mathrm{kWh}$ while the energy savings of low melting temperature PCMs (PCM 18-21) during these months were the highest and reached up to $50.47 \mathrm{kWh}$. This is due to the reason that in the 


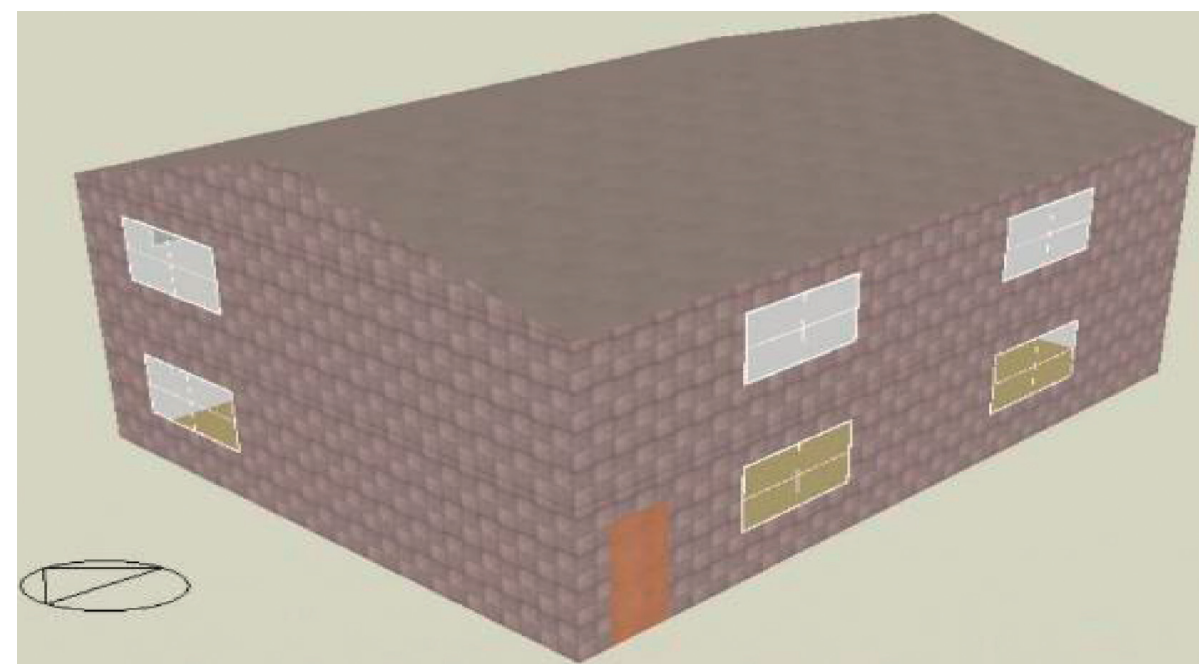

Figure 3: Model of the two-storey reference residential building.

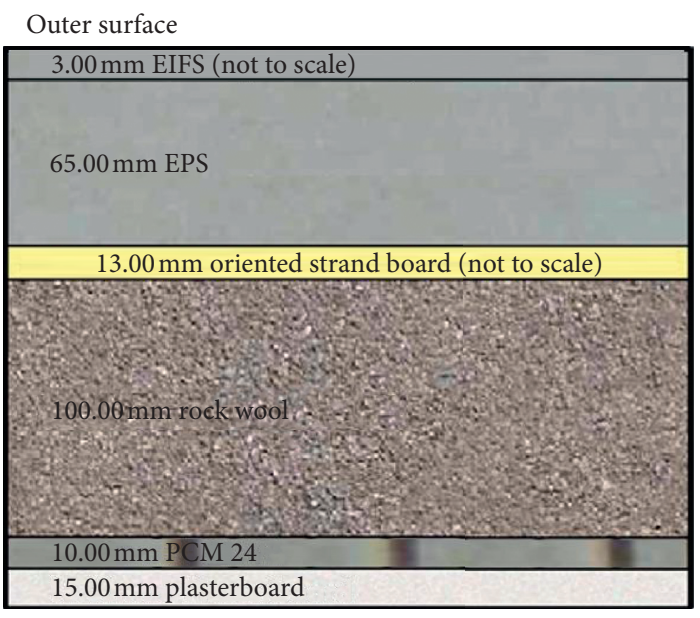

Inner surface

(a)

Outer surface

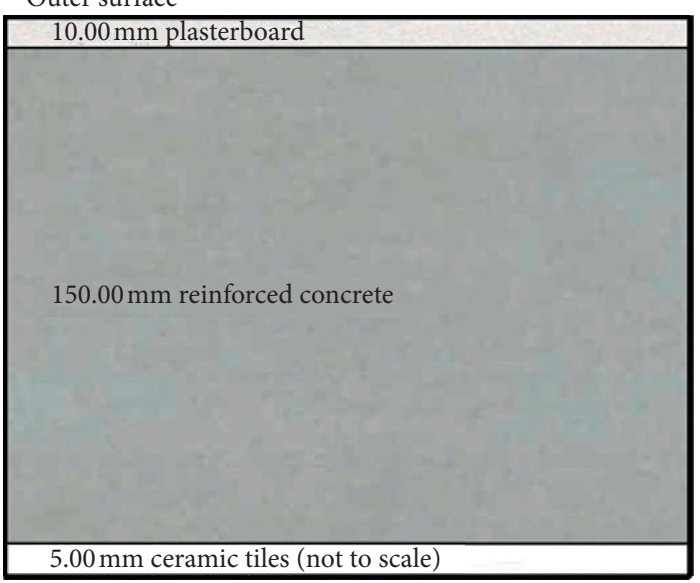

Inner surface

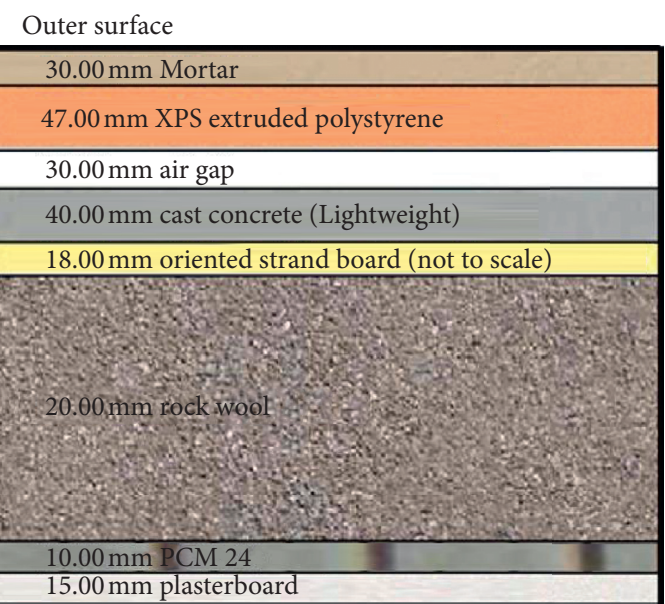

Inner surface

(b)

Outer surface

\begin{tabular}{|c|}
\hline $10.00 \mathrm{~mm}$ timber flooring-interior finishing \\
\hline $40.00 \mathrm{~mm}$ cast concrete (Lightweight) \\
\hline $40.00 \mathrm{~mm}$ XPS extruded polystyrene \\
\hline \\
$100.00 \mathrm{~mm}$ gravel \\
\hline
\end{tabular}

(d)

FIGURE 4: Detailed illustrations of wall, roof, and floors composition. (a) Wall composition. (b) Roof composition. (c) Intermediate floor (d) Slab-on-grade. 
TABLe 2: Thermophysical properties of building materials [21].

\begin{tabular}{|c|c|c|c|c|}
\hline Material & Thickness (mm) & Thermal conductivity $(\mathrm{W} / \mathrm{mK})$ & Specific heat $(\mathrm{J} / \mathrm{kgK})$ & Density $\left(\mathrm{kg} / \mathrm{m}^{3}\right)$ \\
\hline \multicolumn{5}{|c|}{ Wall composition } \\
\hline EIFS finish & 3.00 & 1.150 & 1500 & 1050 \\
\hline EPS & 65.00 & 0.040 & 1400 & 15 \\
\hline OSB & 13.00 & 0.130 & 1700 & 650 \\
\hline Rockwool & 100.00 & 0.040 & 840 & 30 \\
\hline PCM & 10.00 & 0.200 & 1970 & 860 \\
\hline Plasterboard & 15.00 & 0.250 & 1000 & 1200 \\
\hline \multicolumn{5}{|c|}{ Roof composition } \\
\hline Mortar slab & 30.00 & 0.880 & 896 & 2800 \\
\hline XPS & 47.00 & 0.034 & 1400 & 35 \\
\hline Cast concrete & 40.00 & 0.38 & 1000 & 1200 \\
\hline OSB & 18.00 & 0.130 & 1700 & 650 \\
\hline Rockwool & 200.00 & 0.040 & 840 & 30 \\
\hline PCM & 10.00 & 0.200 & 1970 & 860 \\
\hline Plasterboard & 15.00 & 0.250 & 1000 & 1200 \\
\hline \multicolumn{5}{|c|}{ Intermediate floor composition } \\
\hline Plasterboard & 10.00 & 0.250 & 1000 & 1200 \\
\hline Reinforced concrete & 150.00 & 1.58 & 880 & 2288 \\
\hline Ceramic tiles & 5.00 & 1.5 & 840 & 2500 \\
\hline \multicolumn{5}{|c|}{ Slab-on-grade composition } \\
\hline Interior finishing & 10.00 & 0.170 & 1400 & 1200 \\
\hline Cast concrete & 40.00 & 0.38 & 1000 & 1200 \\
\hline XPS & 40.00 & 0.034 & 1400 & 35 \\
\hline Gravel & 100.00 & 2.800 & 800 & 2500 \\
\hline
\end{tabular}

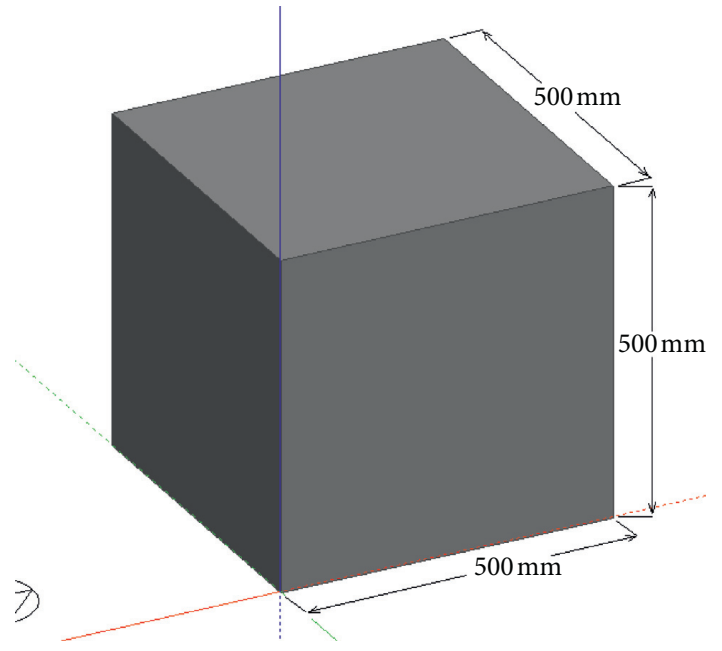

FIGURE 5: Simulation model.

winter season the outside temperature is lower and the melting process in low melting point PCM can take place easily [31]. However, the negative energy savings with low melting PCMs (PCM 18 and PCM 19) were recorded in February and March. For instance, $-18.78 \mathrm{kWh}$ of energy savings were obtained with PCM 18 in February and -0.73 kWh of energy savings in March. Soares et al. [21] analyzed the energy efficiency of lightweight steel-framed (LSF) residential single-zone building and found that the indicators of energy savings in December in Warsaw, which is also located in the Dfb climate zone, had negative results. Therefore, a more in-depth analysis should be done to investigate the reason for negative energy savings in some winter and spring months in cities with warm summer humid continental climate. As far as the energy savings of high melting temperature PCMs (PCMs 25-28) during these months is concerned, it was relatively small and mostly identical. The similarity in the results of high melting point PCMs can be explained by additional thermal capacity provided by the inclusion of the PCM layer [21]. In June, July, and August, cooling demand was only required and ranged from $600.19 \mathrm{kWh}$ to $912.66 \mathrm{kWh}$. The energy savings for high melting temperature PCMs in these months reached up to $53.99 \mathrm{kWh}$ while for low melting temperature PCMs, the energy savings are negligible and varied from 1.56 to 5.97 $\mathrm{kWh}$. An interesting result of negative energy savings especially for high melting point PCMs can also be observed in August. This shows that PCMs with high melting point have actually increased the cooling demand of building by releasing the accumulated energy to the indoor environment. For Kiruna city belonging to Dfc climate region, Soares et al. [21] found that in single-zone living room incorporated with optimum PCM, the energy required for cooling increased when compared with no PCM case and negative values of energy savings were obtained. It can also be noticed from the figure that despite the relatively lower total energy consumption in April (92.77 kWh), May (298.95 kWh), September (226.63 kWh), and October (169.77 kWh), the energy savings in these months were considerably high and ranged from $61.42 \mathrm{kWh}$ (April) up to $109.34 \mathrm{kWh}$ (May).

In Toronto, the heating and cooling energy consumption stages are similar to Helsinki. In January, February, March, November, and December, heating energy consumption was only required and it varied from $380.93 \mathrm{kWh}$ to $896.76 \mathrm{kWh}$. As in Helsinki, the energy savings of low melting 


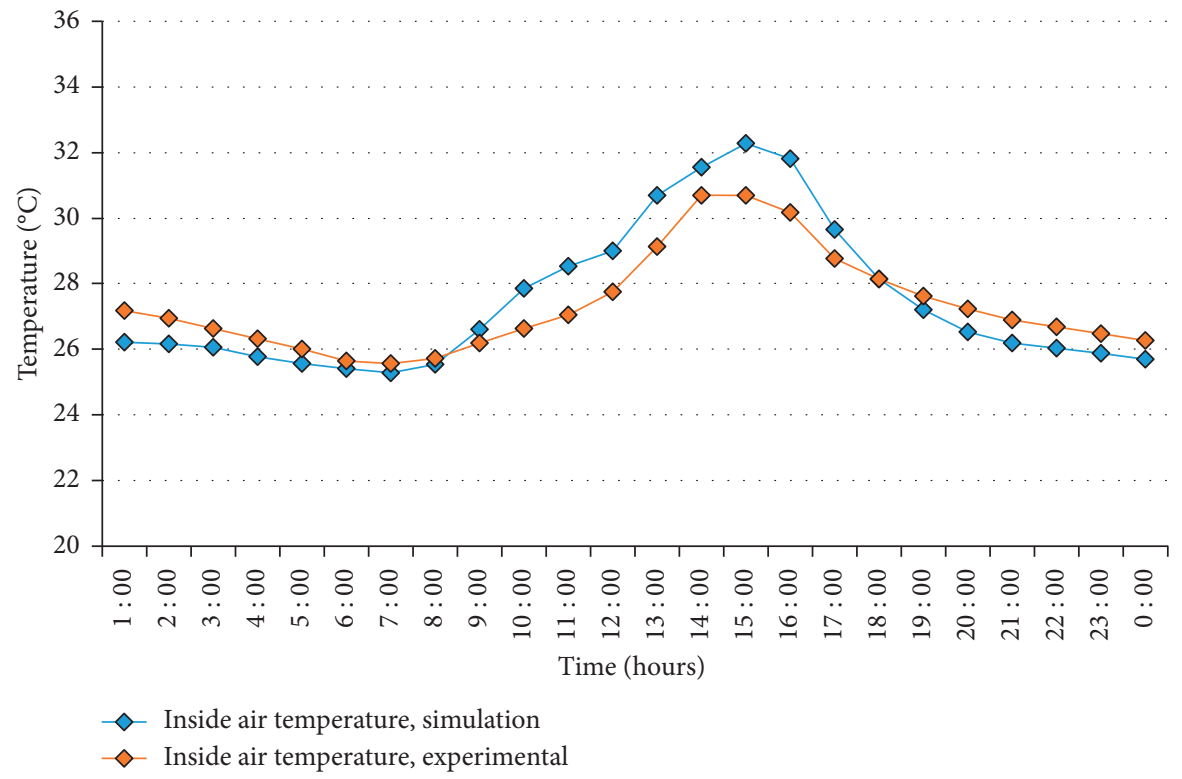

FIGURE 6: Validation of simulation data against experimental data.

temperature PCMs (PCMs 18-21) during those months were on the higher side (up to $81.32 \mathrm{kWh}$ ) whereas the energy saving potential of high melting temperature PCMs (PCMs 25-28) was mostly identical and resulted in small energy savings (up to $15.16 \mathrm{kWh}$ ). In June, July, and August, the cooling demand in residential building integrated with PCMs was higher than the residential building integrated without PCM. Finally, the total energy consumption in April, May, September, and October was lower when compared with other months. However, as in Helsinki, the energy savings during these months were on the higher side and reached up to $128.34 \mathrm{kWh}$ in May.

On the basis of the above discussion, it can be derived that PCM with various melting temperatures showed different efficiency in each month of the year. In the months where heating demand is only required (January, February, March, November, and December), the low melting temperatures PCMs (PCMs 18-21) behaved efficiently while high melting temperature PCMs (PCMs 25-28) mostly showed identical performance with small energy savings. However, in the months where cooling demand is only required (June, July, and August), the high melting temperature PCMs showed varied performance; that is, in some cities it showed higher efficiency while in other cities it showed poor performance. Moreover, throughout the transition months (April, May, September, and October), the energy savings were on the higher side and both low and high melting temperature PCMs have the opportunity to achieve maximum energy savings. For example, PCM 21 in Kiev saved $91.25 \mathrm{kWh}$ in October while PCM 25 in Saint Petersburg saved $142.14 \mathrm{kWh}$.

3.2. Thermal Response of Buildings Located in Warm Summer Humid Continental Climate. In order to investigate the thermal behaviour of phase change materials under controlled temperature conditions (HVAC switched on), the inside air temperature profiles in each examined city were compared in buildings integrated with and without PCM. For this purpose, the months representing the greatest and lowest output in relation to monthly energy savings were defined. For eight examined cities, the months showing the peak performance with regard to energy savings were April, May, September, and October (fallspring seasons). The optimum PCMs during these months in the selected eight cities were PCM 21 and PCMs 23-26. Figure 8 shows three consecutive days of indoor air temperature for the reference building and associated air temperature of the optimum PCM, which was incorporated into the reference building. For convenience, the outside temperature is also plotted.

In Helsinki, during the first day, the outside temperature changed from $3.32^{\circ} \mathrm{C}$ at $4: 00 \mathrm{hrs}$ to $19.14^{\circ} \mathrm{C}$ at $15: 00 \mathrm{hrs}$ while the solar radiation reached up to $870 \mathrm{~W} \cdot \mathrm{m}^{-2}$ (Figure 9). According to temperature profiles of the reference building, the peak indoor air temperature during the first day reached $27.28^{\circ} \mathrm{C}$ while the indoor temperature in residential building incorporated with PCM 26 (optimum PCM) reached $26.39^{\circ} \mathrm{C}$. During the second day, the fluctuation in outside temperature was small and it varied from $11.46^{\circ} \mathrm{C}$ at $5: 00 \mathrm{hrs}$ to $15.42^{\circ} \mathrm{C}$ at $17: 00 \mathrm{hrs}$ with maximum solar radiation reaching up till $110 \mathrm{~W} \cdot \mathrm{m}^{-2}$. The inside temperature in the residential building with and without PCM reached $25.33^{\circ} \mathrm{C}$ and $25.40^{\circ} \mathrm{C}$, respectively. On the third day, the outside temperature reached $21.91^{\circ} \mathrm{C}$ at $15: 00 \mathrm{hrs}$ and solar radiation reached up till to $760 \mathrm{Wm}^{-2}$. During this day, the indoor temperature in residential building incorporated with and without $\mathrm{PCM}$ reached $26.93^{\circ} \mathrm{C}$ and $27.96^{\circ} \mathrm{C}$, respectively. Therefore, during the three consecutive days, the temperature reduction varied from $0.07^{\circ} \mathrm{C}$ (on day 2) to $1.03^{\circ} \mathrm{C}$ (on day 3 ), which identifies the ability of PCM to decrease peak temperature. As far as temperature 

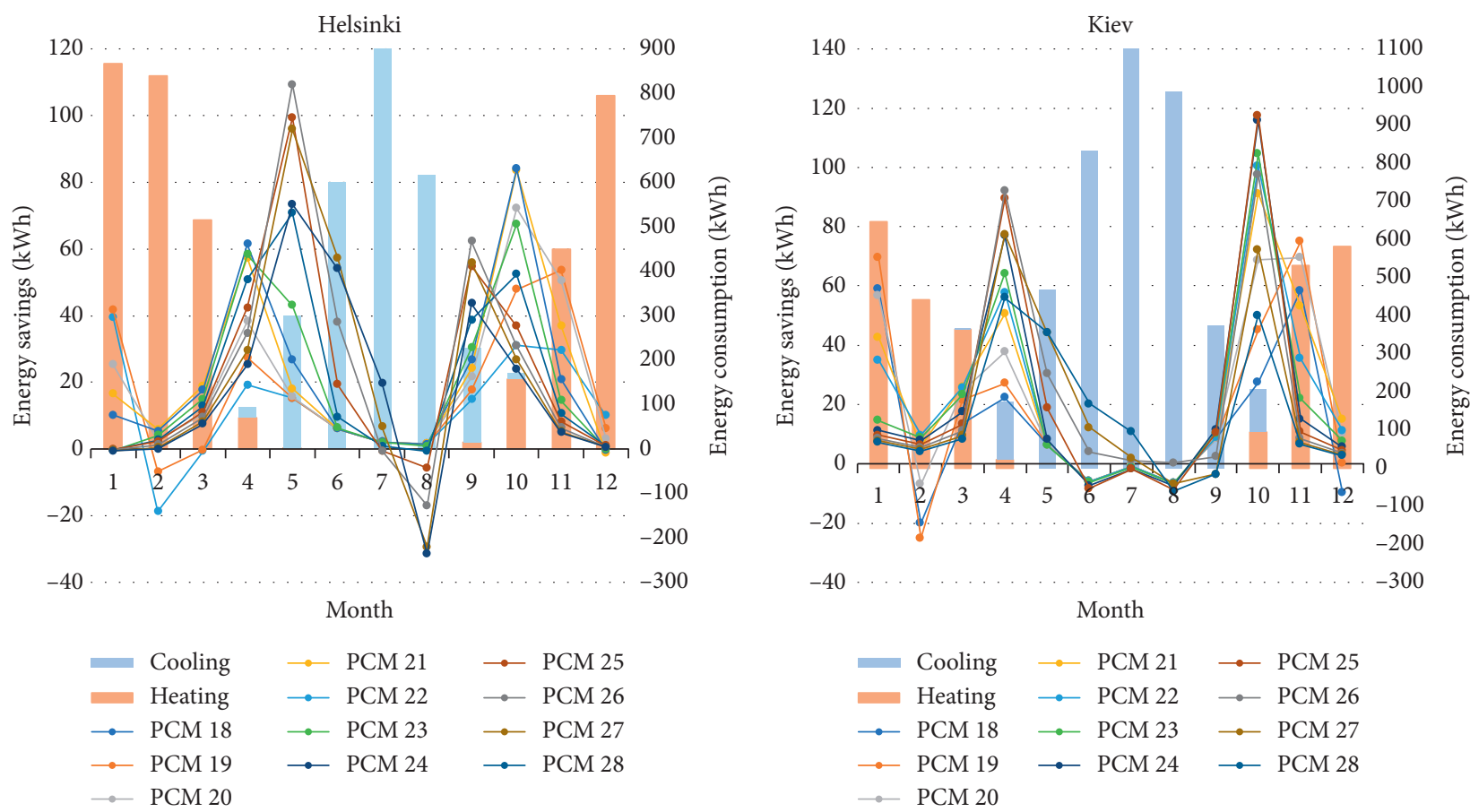

(a)
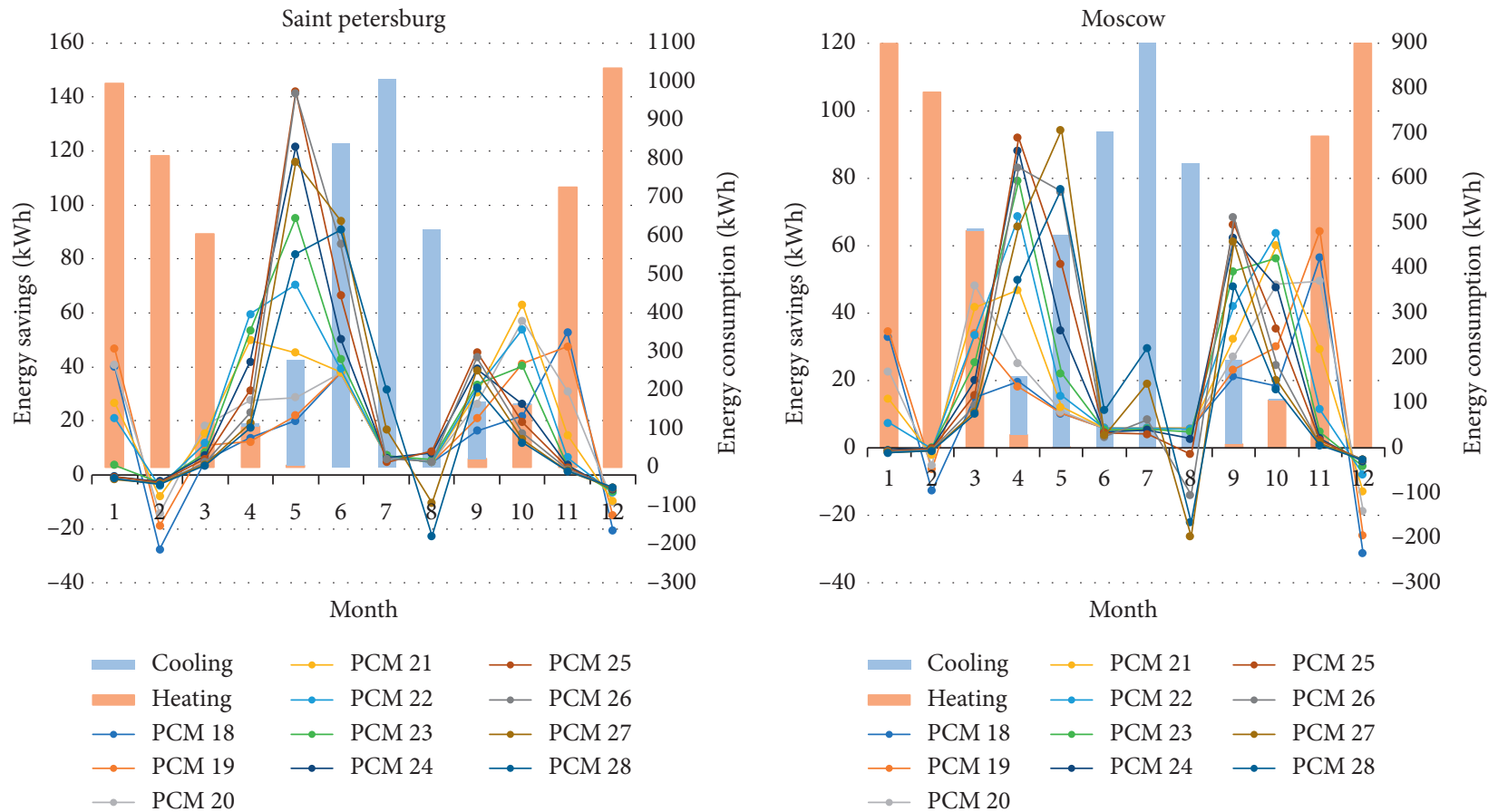

(c)

(d)

Figure 7: Continued. 


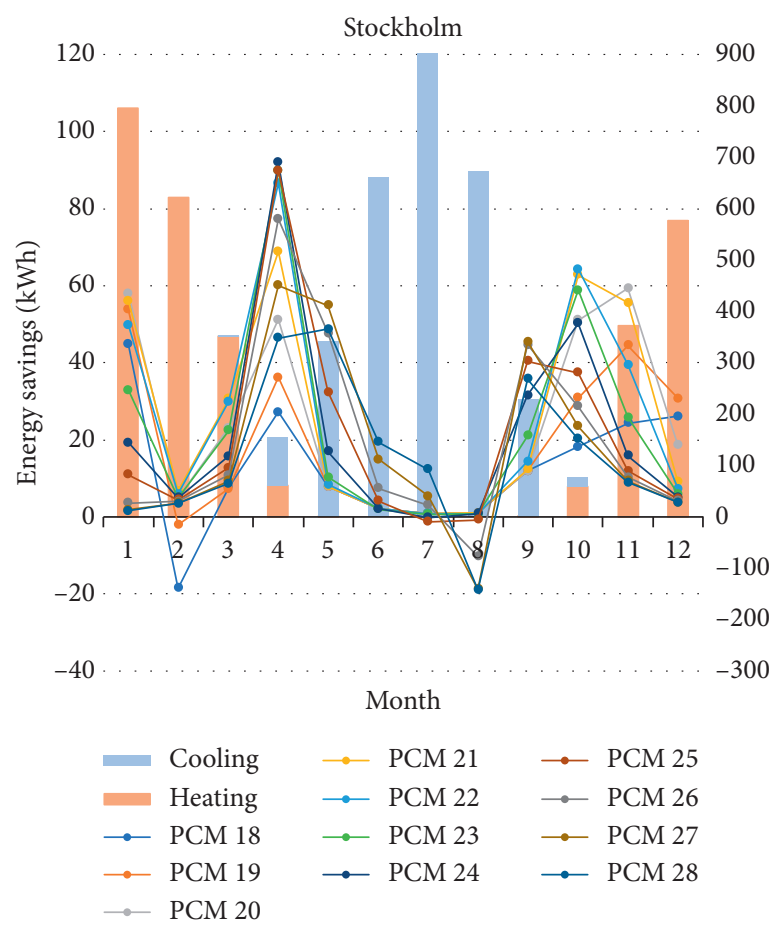

(e)

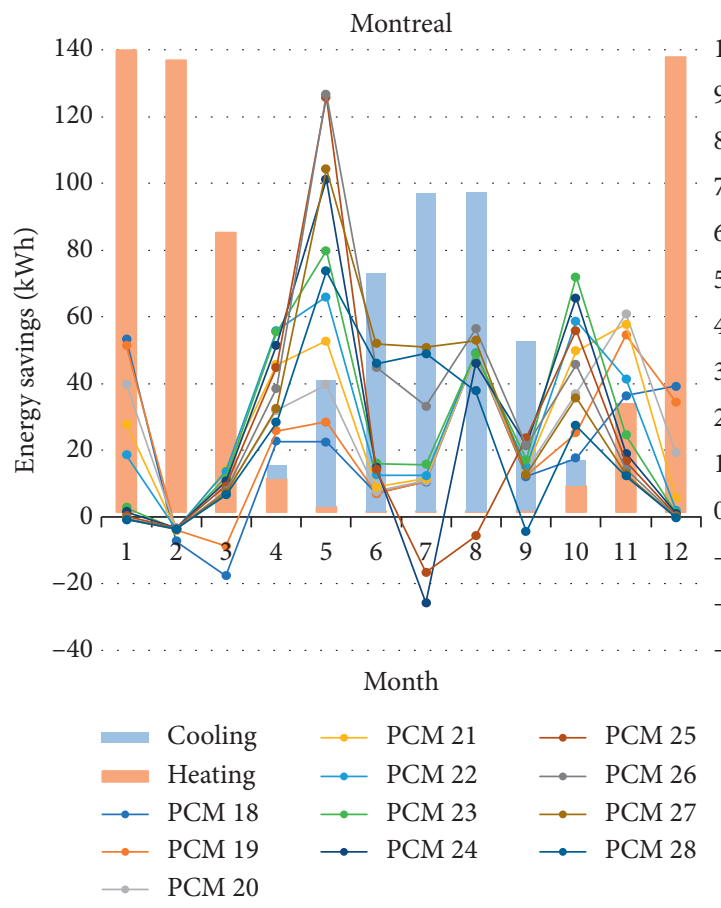

(g)

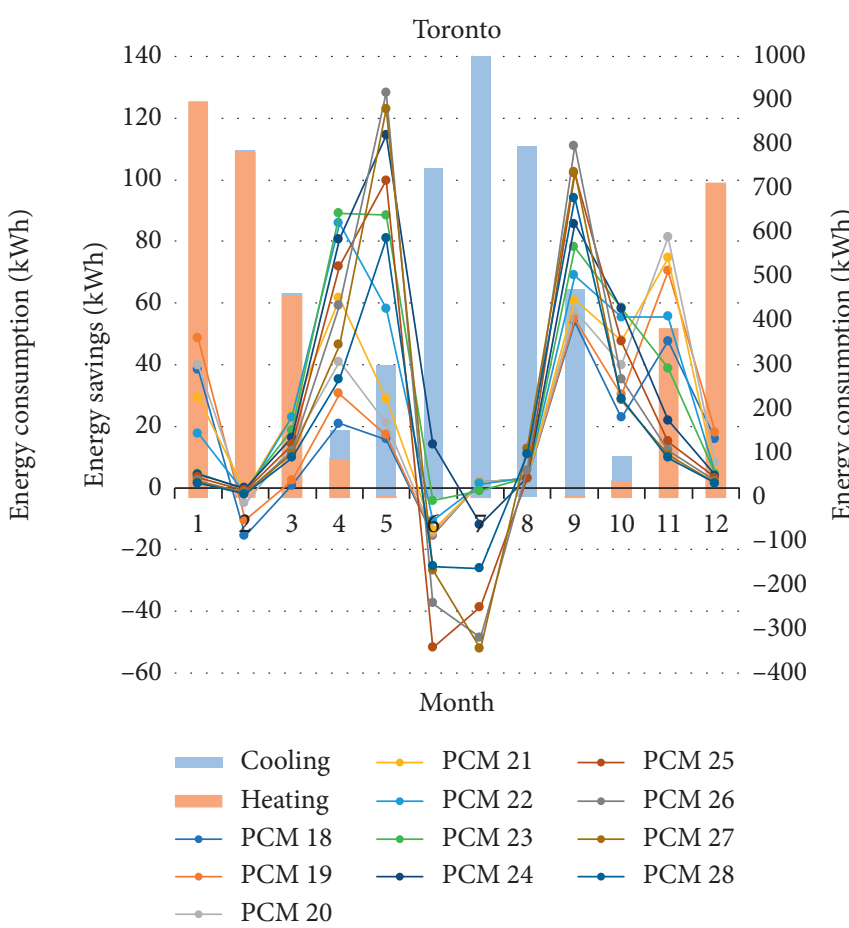

(f)

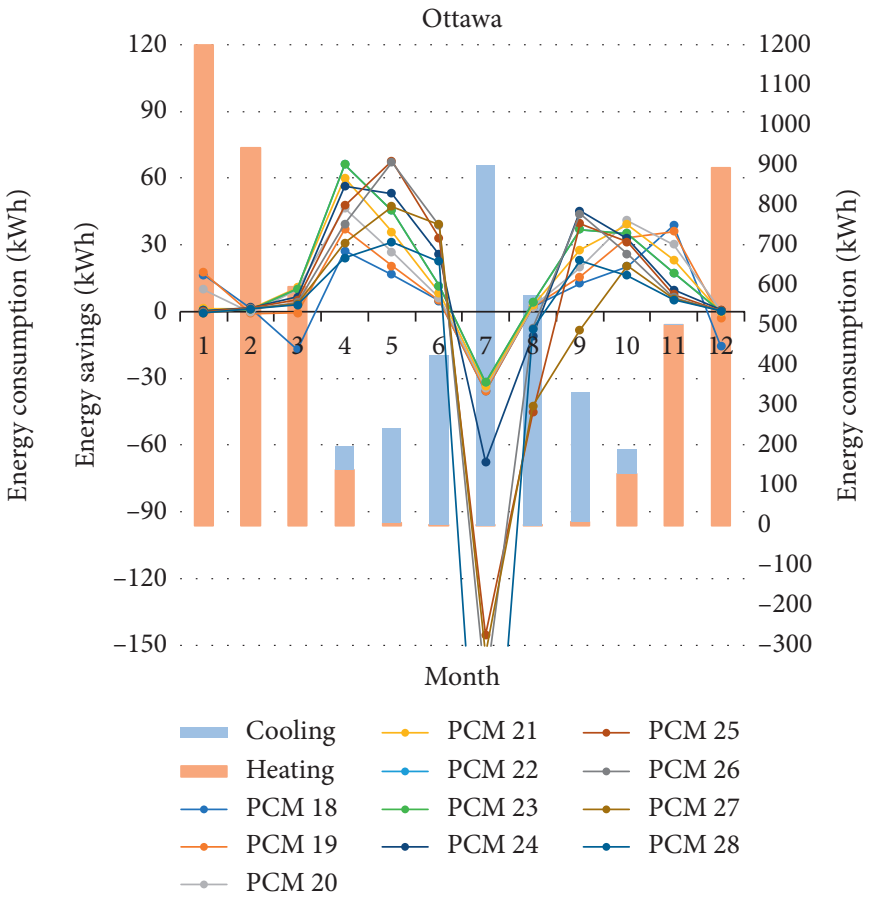

(h)

FIGURE 7: Monthly energy consumption and savings results for all PCMs in eight cities.

fluctuations are concerned, the temperature fluctuation in the residential building without PCM varied from $24.18^{\circ} \mathrm{C}$ to $27.96^{\circ} \mathrm{C}$, while the temperature fluctuation in the residential building with PCM 26 varied from $24.04^{\circ} \mathrm{C}$ to $26.93^{\circ} \mathrm{C}$. This shows that in comparison to the reference building (without PCM), PCM incorporated building was able to diminish the temperature fluctuations by up to $0.89^{\circ} \mathrm{C}$.
As far as other cities are concerned, in comparison to the reference building (without PCM), the residential building integrated with optimum phase change material reduced the maximum indoor temperature in Kiev, Saint Petersburg, Moscow, Stockholm, Toronto, Montreal, and Ottawa by $1.03^{\circ} \mathrm{C}, 1.98^{\circ} \mathrm{C}, 1.91^{\circ} \mathrm{C}, 1.48^{\circ} \mathrm{C}, 0.94^{\circ} \mathrm{C}, 1.14^{\circ} \mathrm{C}$, and $1.07^{\circ} \mathrm{C}$, respectively. Moreover, due to incorporation of PCM in 

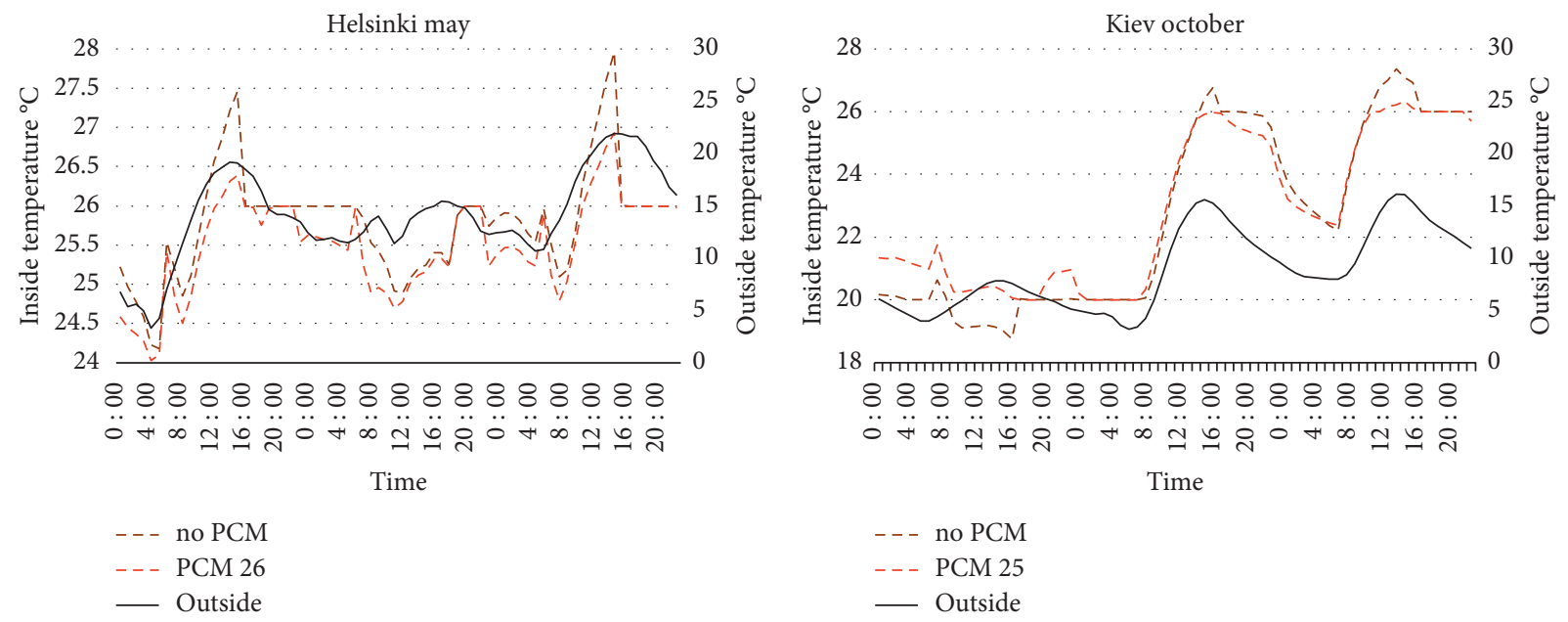

(a)
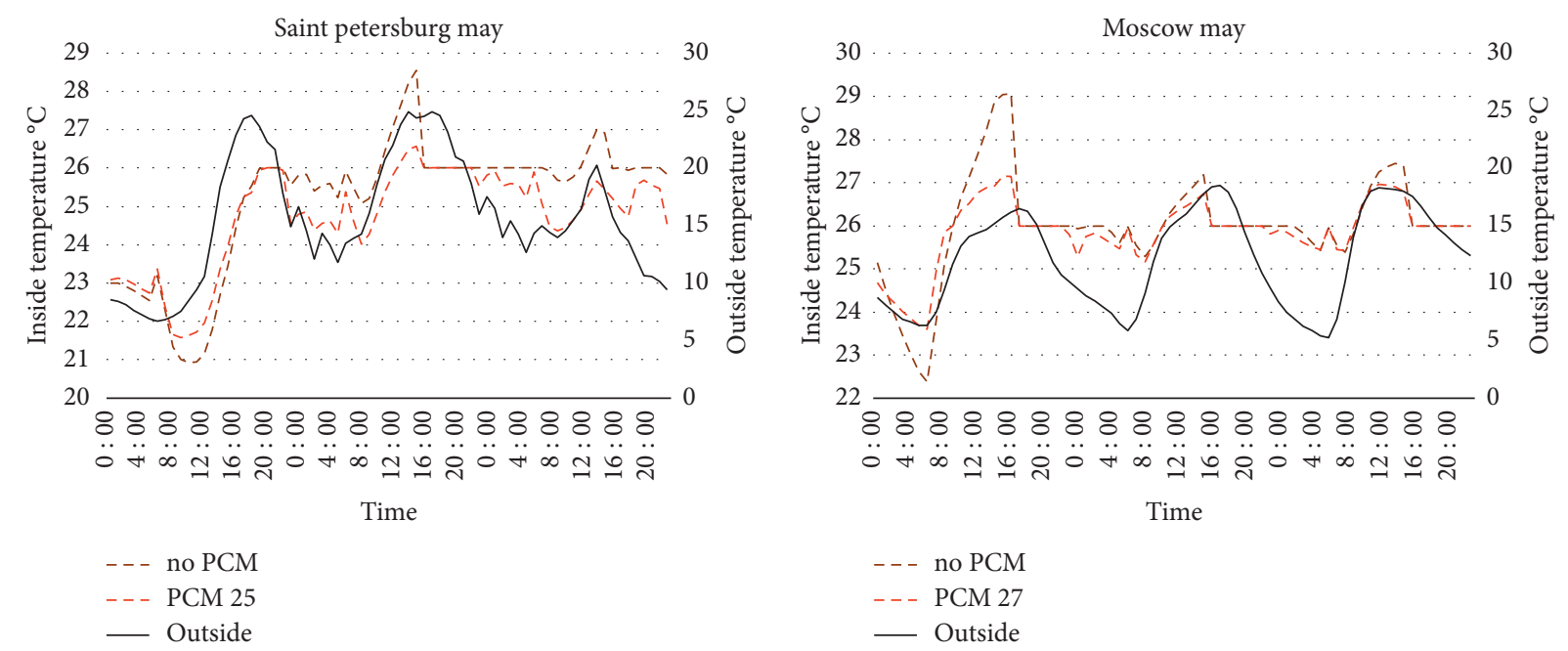

(c)

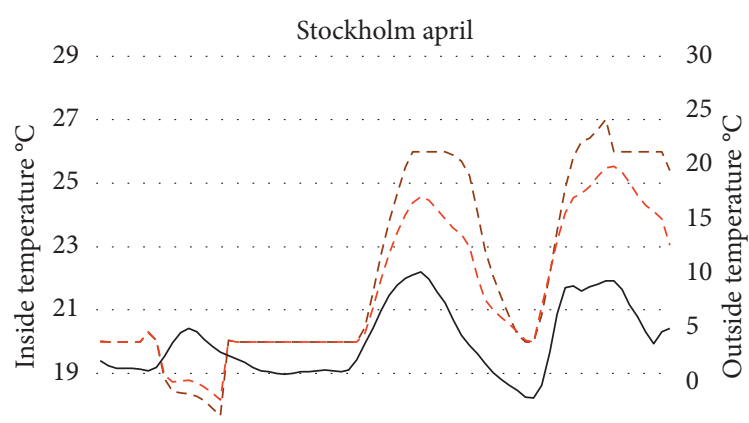

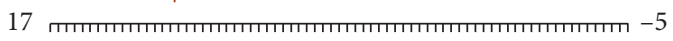

৪৪৪৪৪৪৪৪৪৪৪৪৪৪৪৪৪৪

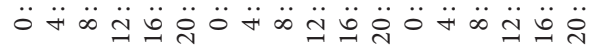

Time

(d)

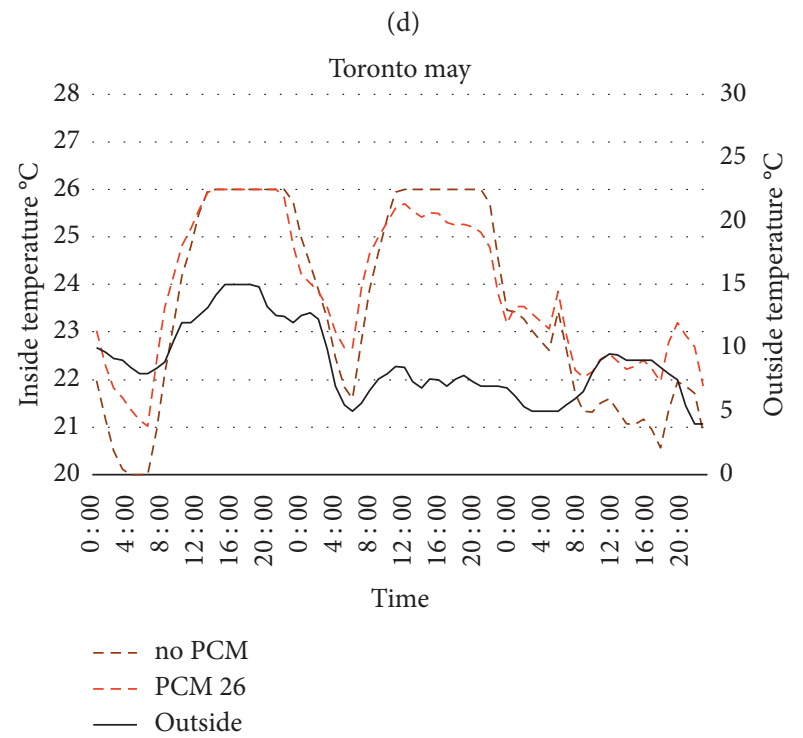

(e)

Figure 8: Continued. 


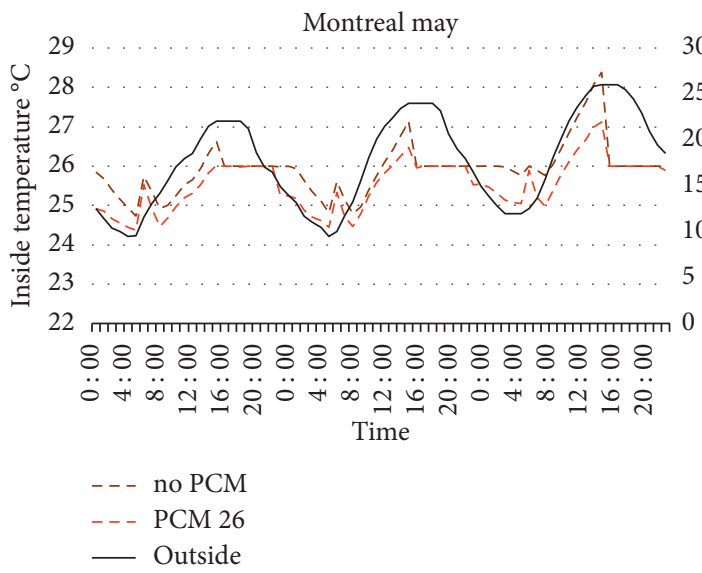

(g)

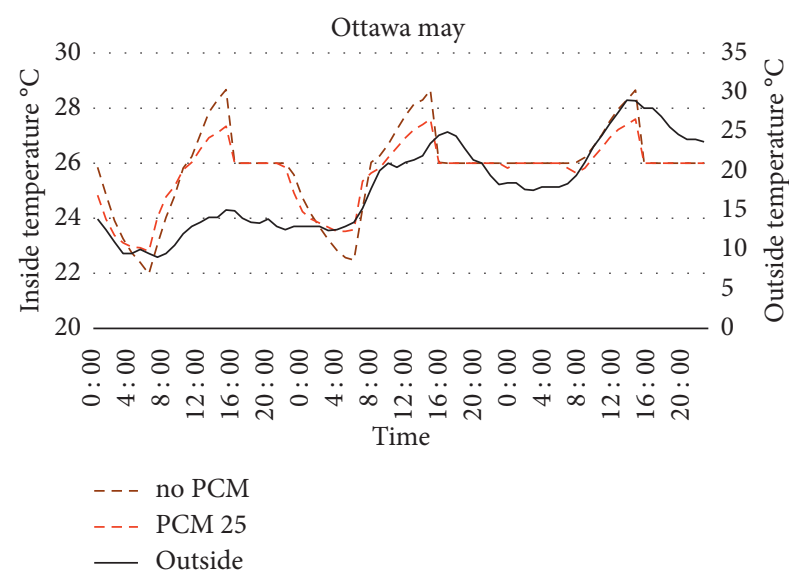

(h)

FiguRE 8: Temperature profiles for all cities for months with the greatest energy savings.

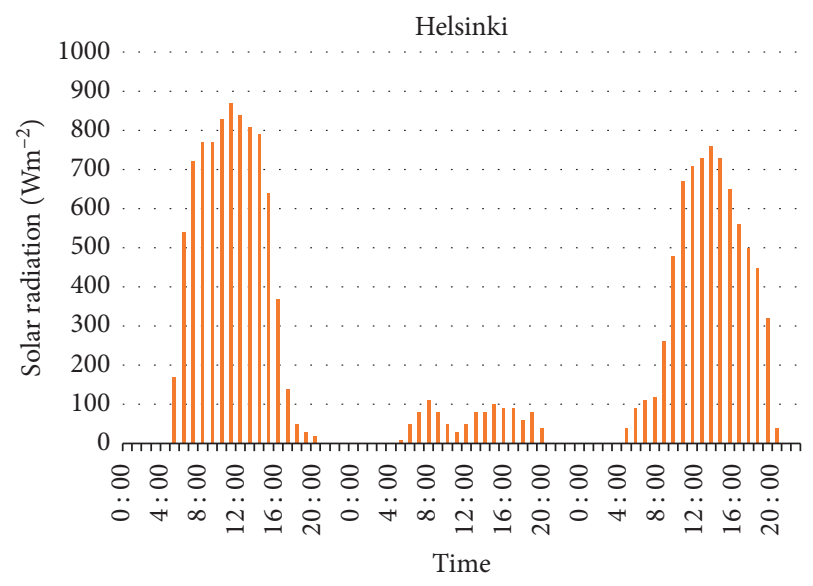

FIgURE 9: Solar radiation values in Helsinki.

building, the temperature fluctuation in these cities reduced by $2.27^{\circ} \mathrm{C}, 2.63^{\circ} \mathrm{C}, 3.13^{\circ} \mathrm{C}, 1.98^{\circ} \mathrm{C}, 1.96^{\circ} \mathrm{C}, 0.66^{\circ} \mathrm{C}$, and $1.89^{\circ} \mathrm{C}$, respectively. Thus, the complete phase change cycle of the PCM occurred and reductions in maximum temperature and fluctuation reductions were achieved. When the temperature exceeds the melting temperature of PCM, PCM is able to transform into liquid form by taking the overheating load. During the night, when the inside temperature falls to solidification temperature, PCM is able to return to a solid form by releasing the stored heat [34]. It can also be observed from Figure 8 that for some cities (Stockholm and Toronto), higher indoor temperature was obtained even when the outdoor temperature was lower. While investigating the efficiency of PCM impregnated rectangular single-zone building model in Madrid climate, the higher inner surface temperature was obtained when the outside air temperature was lower and solar radiations were on the higher side [31]. From the above discussion, two important parameters were highlighted: (1) the peak temperature decrease and (2) temperature fluctuation reduction. For the analyzed cities, the maximum peak temperature decrease varied from $1.03^{\circ} \mathrm{C}$ in Helsinki and Kiev to $1.98^{\circ} \mathrm{C}$ in Saint Petersburg while the temperature fluctuation reduction values ranged from $0.88^{\circ} \mathrm{C}$ in Helsinki to $3.13^{\circ} \mathrm{C}$ in Moscow. The results clearly show that not only are PCMs able to lower the maximum temperature peaks but also they are able to lower the temperature variations in buildings, thus, enhancing the indoor thermal conditions. The findings are in line with available literature [35-38].

For the eight selected cities, the months showing the poor performance with respect to energy savings were June, July, and August. In order to perform an in-depth analysis, the PCMs showing best and worst performance in the above months were selected. For demonstration purpose, the outcomes of two cities each from Europe (Saint Petersburg and Moscow) and North America (Toronto and Ottawa) are presented. Figure 10 shows three consecutive days (the $1^{\text {st }}$, $2^{\text {nd }}$, and $3^{\text {rd }}$ days of each month) of indoor air temperature for the reference building and associated air temperature of the best and worst PCMs, which were incorporated into the reference building. The outside temperature is also plotted.

In Toronto, the outside temperature during the first day was $18.33^{\circ} \mathrm{C}$ at $2: 00 \mathrm{hrs}$; it rose to $25.52^{\circ} \mathrm{C}$ at $15: 00 \mathrm{hrs}$ and then decreased to $21.62^{\circ} \mathrm{C}$ at $20: 00 \mathrm{hrs}$. The solar radiation released reached a maximum value of $860 \mathrm{Wm}^{-2}$ (Figure 11) at 15:00 hrs. The maximum indoor temperature reached $28.27^{\circ} \mathrm{C}, 28.34^{\circ} \mathrm{C}$, and $28.43^{\circ} \mathrm{C}$ in the residential building without PCM, PCM 18, and PCM 28. On the second day, the outside temperature fluctuation was from $21^{\circ} \mathrm{C}$ to $28^{\circ} \mathrm{C}$ while the solar radiations reached a maximum value of $410 \mathrm{Wm}^{-2}$ at $10: 00 \mathrm{hrs}$. Based on the temperature profiles, the peak temperatures reached in the building without phase change material, PCM 18 , and PCM 28 were $27.49^{\circ} \mathrm{C}, 27.64^{\circ} \mathrm{C}$, and $28.14^{\circ} \mathrm{C}$, respectively. Similarly, on the third day, the outside temperature changed from $21.79^{\circ} \mathrm{C}$ at $8: 00 \mathrm{hrs}$ to $25.00^{\circ} \mathrm{C}$ at $18: 00 \mathrm{hrs}$ while the maximum value of solar radiation was obtained at $06: 00$ and $11: 00 \mathrm{hrs}\left(190 \mathrm{Wm}^{-2}\right)$. The temperature profiles at peak time were $25.48^{\circ} \mathrm{C}$ for the wall without PCM and $25.79^{\circ} \mathrm{C}$ and $26.86^{\circ} \mathrm{C}$ for the wall with PCM 18 and PCM 28, respectively. Based on the above 


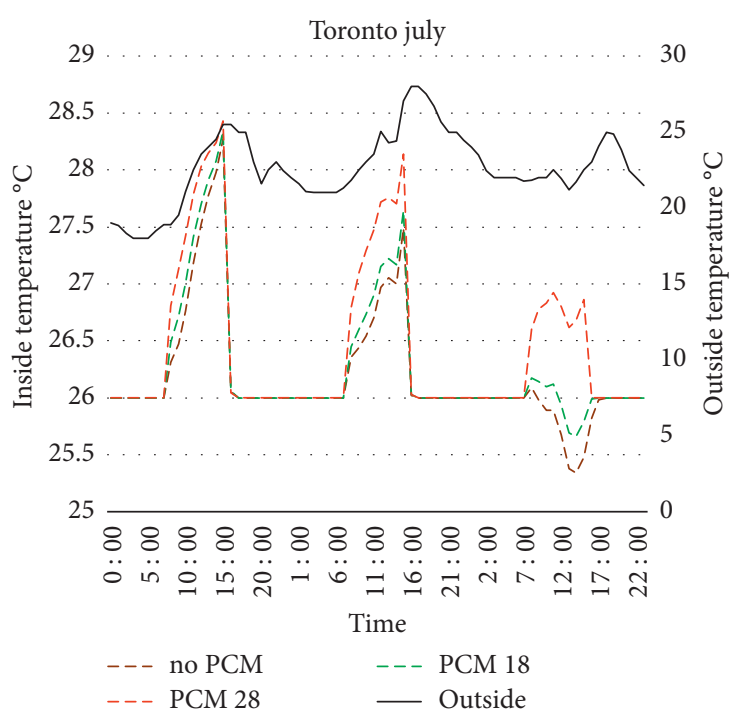

(a)

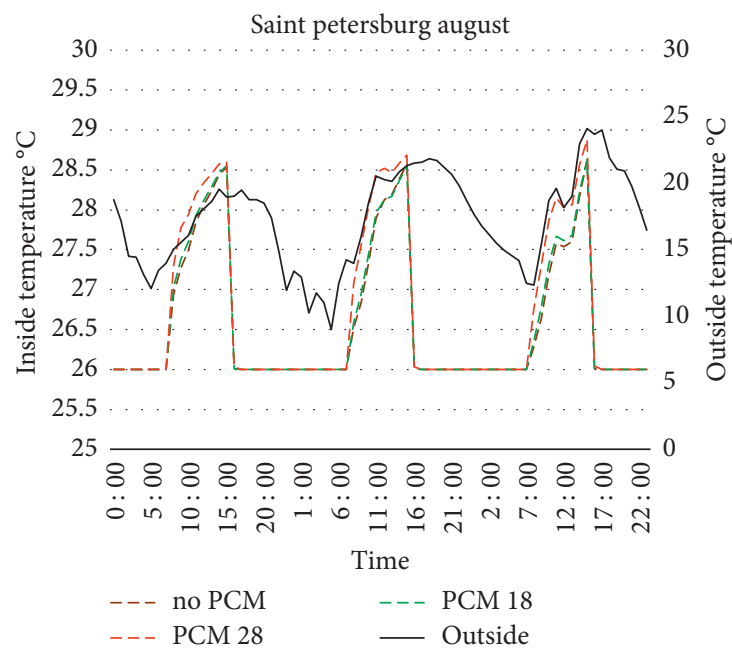

(c)

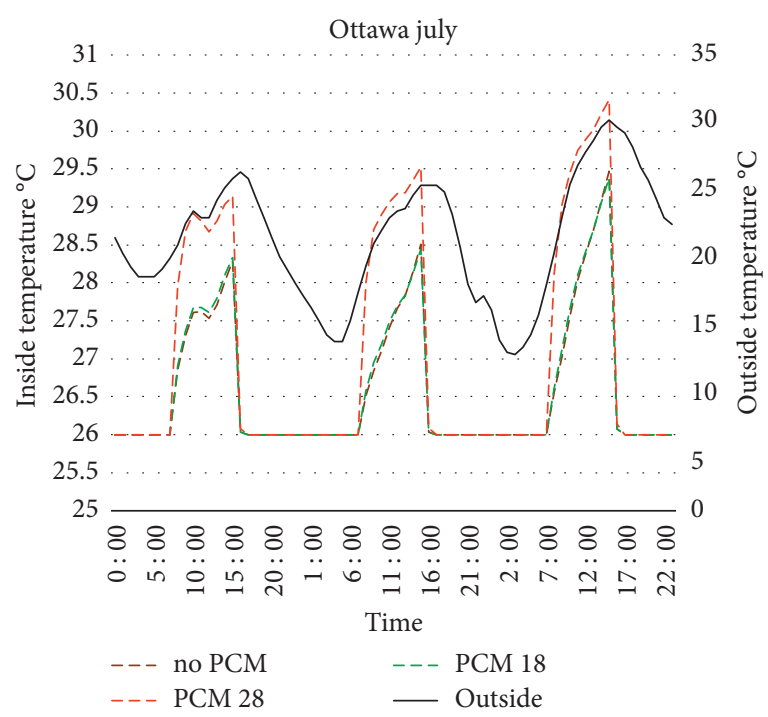

(b)

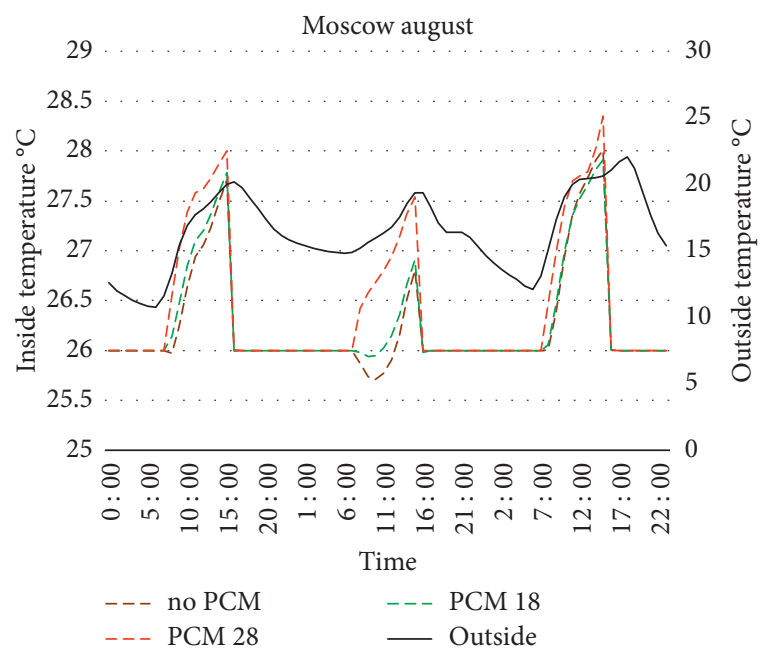

(d)

FIGURE 10: Temperature profiles for representative cities for months with the lowest energy savings.

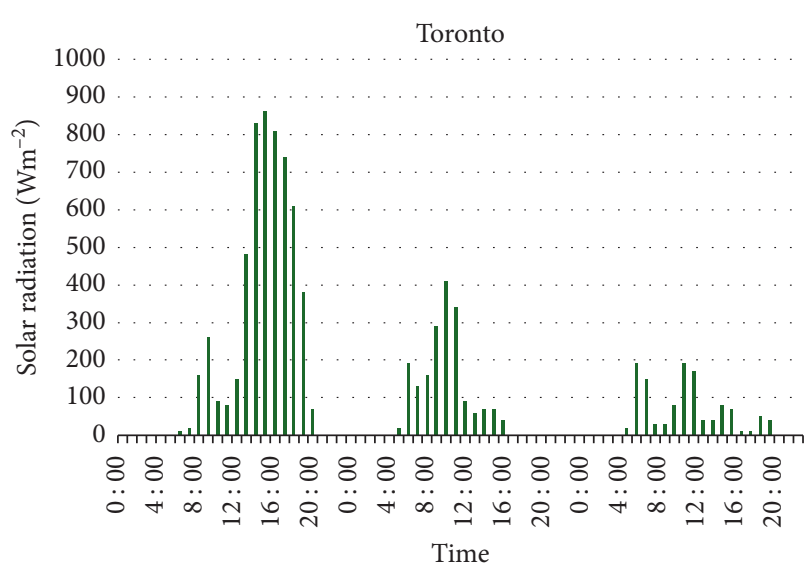

FIgURE 11: Solar radiation values in Toronto. discussion, it is clear that the pattern of temperature profile for PCM 18 is almost similar to that of no PCM case while PCM 28 showed the worst thermal performance. For PCM 18 , the high outside temperature in conjunction with solar radiation firmly increased PCM 18 temperature during the day. However, during the nighttime, the temperature inside the building remained at $26^{\circ} \mathrm{C}$ thus forbidding even partial solidification of PCM 18. Hence, the ineffectiveness of PCM during this month is due to the reason that PCM 18 is always in a liquid state. According to Souayfane [39], the inability of solidification limits the potential of PCM and causes overheating and thus reduces the efficiency of PCM.

Considering the performance of PCM 28, the higher outdoor temperature, along with solar radiation, allows PCM 28 to melt during the daytime. During the nighttime, the average inside air temperature stays at $26^{\circ} \mathrm{C}$. This 
shows that PCM is transforming its state from solid to liquid and is discharging the heat that was stored during the day. Since the phase change material is placed next to the inner surface of the wall hence the heat is being released to the inside environment of the building, which in turn, increases the inside temperature of the building and increases the work needed by the HVAC to regulate thermal comfort. For the lightweight steel-framed singlezone living room, Soares et al. [21] reported negative values of energy savings in summer meaning that stored heat in PCM was released to an indoor environment, which, in turn, increased the energy demand required for cooling. It is pertinent to mention here that similar behaviour was observed for Saint Petersburg, Moscow, and Ottawa cities. For these cities, the maximum decrease in peak temperature was up to $0.1^{\circ} \mathrm{C}$.

3.3. Annual Assessment of PCM-Integrated Buildings. This section provides the results of annual energy savings in eight different cities of Dfb climate are presented. Figure 12 shows the results of heating, cooling, and total energy savings for the optimum PCM in different cities of Dfb climate. In Figure 12, the bar represents the optimum PCM for each city while the lines indicate heating, cooling, and total energy savings obtained in these cities. This illustration provides a clear visualization of how heating and cooling energy savings influence the selection of optimum phase change material for each city.

It is clear that the values of cooling and heating energy savings differ from city to city. The cooling energy savings are high in Helsinki (214.77 kWh), Moscow (207.79 kWh), Saint Petersburg (257.68 kWh), Toronto (294.75 kWh), and Montreal $(329.95 \mathrm{kWh})$ while heating energy savings are high in Kiev (221.45 kWh) and Stockholm (233.39 kWh). The total energy savings varied from $196.55 \mathrm{kWh}$ (Ottawa) up to $391.07 \mathrm{kWh}$ (Toronto). An interesting phenomenon can be observed. The pattern of heating and cooling energy savings strongly affects the selection of optimum phase change material found for each city. For Kiev and Stockholm, where heating savings are high, the optimum PCM was found to be PCM 21, which is nearby the low boundary of the thermal comfort zone $\left(20^{\circ} \mathrm{C}\right)$. Similarly, in the cities where cooling energy savings are higher (Helsinki, Saint Petersburg, Moscow, Toronto, and Montreal), the optimum PCM ranged from PCM 24 to 26 and was close to the upper boundary of the thermal comfort zone $\left(26^{\circ} \mathrm{C}\right)$. For Ottawa, where both heating and cooling demand are close to each other, the optimum PCM was PCM 23.

Some researchers have analyzed the efficiency of PCM in Dfb climate region. For instance, Marin et al. [9] examined the energy saving potential of PCM 25 installed in singlezone relocatable lightweight building equipped with packaged terminal heat pump (PTHP). The authors found that the annual energy savings in Montreal, Moscow, and Stockholm were low $(<30 \mathrm{KWh})$. The variation in findings is believed to be due to several reasons such as difference in (a) size of building used $(2.4 \mathrm{~m} \times 2.4 \mathrm{~m} \quad x \quad 2.4 \mathrm{~m} \quad$ vs. $12.18 \mathrm{~m} \times 9.16 \mathrm{~m} \times 6.55 \mathrm{~m}$ ), (b) HVAC system used (PTHP

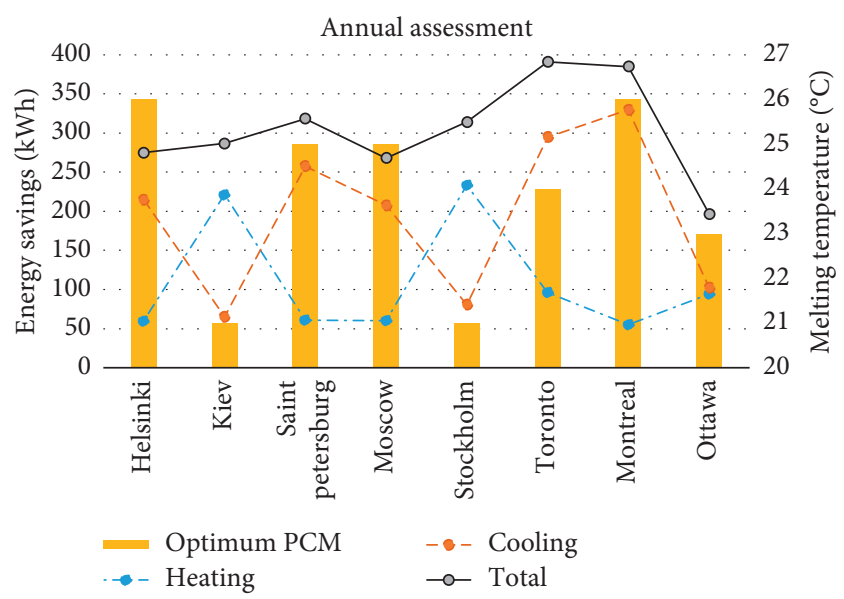

FIGURE 12: Annual heating, cooling, and total savings for all cities with optimum PCM melting temperature.

vs. fan coil with district heating and cooling), (c) thermostat points used $\left(18^{\circ} \mathrm{C}-25^{\circ} \mathrm{C}\right.$ vs. $\left.20^{\circ} \mathrm{C}-26^{\circ} \mathrm{C}\right)$, and (d) composition and thermophysical properties of building components. Saffari et al. [8] utilized a single-objective optimization technique to evaluate the energy saving potential of optimum phase change material in different climate zone. For mid-rise apartment building installed with PTHP system, the optimum PCMs for Montreal, Moscow, and Stockholm were found to be $25.44^{\circ} \mathrm{C}, 24.31^{\circ} \mathrm{C}$, and $21.50^{\circ} \mathrm{C}$. This clearly demonstrates that the optimum PCMs for these cities found in our research are in line with the findings of Saffari et al. [8].

3.4. Effect of PCM Volume on the Energy Efficiency of Buildings. In this section, the impact of PCM volume on the energy efficiency of PCM incorporated building is evaluated. Two scenarios-a varying PCM volume and the constant PCM volume-are analyzed. Firstly, the case when PCM volume is varying is considered (the PCM surface area is kept constant), so that the impact of PCM layer thickness on energy savings and energy consumption reduction is assessed. For this, optimum PCMs determined in Section 3.3 for each city were used, and the thickness of the PCM layer ranged from $10 \mathrm{~mm}$ to $40 \mathrm{~mm}$. Here, only the results of two cities, namely, Saint Petersburg and Kiev, are provided in Table 3. The outcomes indicate that energy savings and energy consumption reduction enhanced with the thickness of the PCM layer being increased. This is the result of an increased amount of heat absorbed by the PCM layer. For a cubic model having a dimension of $3 \times 3 \times 2.8 \mathrm{~m}^{3}$, Lei et al. [40] estimated the effect of thickness of the PCM layer ( 3 to $20 \mathrm{~mm}$ ) integrated on the interior and exterior side of the wall. The findings of this study indicated that increasing the thickness of the PCM layer leads to higher gain reduction rates being achieved. Similar findings were noted by Saffari et al. [31]. The results of energy consumption reduction per $\mathrm{mm}$ for both cities are demonstrated in Table 3. From this Table, higher energy efficiency and lower cost can be obtained by using thinner PCM layer. Similar findings were 
TABLE 3: Energy savings as a function of PCM thickness.

\begin{tabular}{|c|c|c|c|c|}
\hline City & Thickness (mm) & ES (KWh) & ECR (\%) & ECR (\% per $\mathrm{mm})$ \\
\hline \multirow{7}{*}{ Saint Petersburg } & $10 \mathrm{~mm}$ & 318.51 & 4.32 & 0.43 \\
\hline & $15 \mathrm{~mm}$ & 367.05 & 4.98 & 0.33 \\
\hline & $20 \mathrm{~mm}$ & 408.67 & 5.54 & 0.28 \\
\hline & $25 \mathrm{~mm}$ & 431.11 & 5.85 & 0.23 \\
\hline & $30 \mathrm{~mm}$ & 509.96 & 6.92 & 0.23 \\
\hline & $35 \mathrm{~mm}$ & 564.57 & 7.66 & 0.22 \\
\hline & $40 \mathrm{~mm}$ & 618.86 & 8.40 & 0.21 \\
\hline \multirow{7}{*}{ Kiev } & $10 \mathrm{~mm}$ & 243.72 & 3.61 & 0.36 \\
\hline & $15 \mathrm{~mm}$ & 295.29 & 4.37 & 0.29 \\
\hline & $20 \mathrm{~mm}$ & 321.29 & 4.75 & 0.24 \\
\hline & $25 \mathrm{~mm}$ & 351.66 & 5.20 & 0.21 \\
\hline & $30 \mathrm{~mm}$ & 382.98 & 5.67 & 0.19 \\
\hline & $35 \mathrm{~mm}$ & 418.27 & 6.19 & 0.18 \\
\hline & $40 \mathrm{~mm}$ & 450.2 & 6.66 & 0.17 \\
\hline
\end{tabular}

${ }^{*}$ Energy consumption reduction $(\mathrm{ECR})=($ energy consumption no PCM-energy consumption with PCM)/energy consumption no PCM.

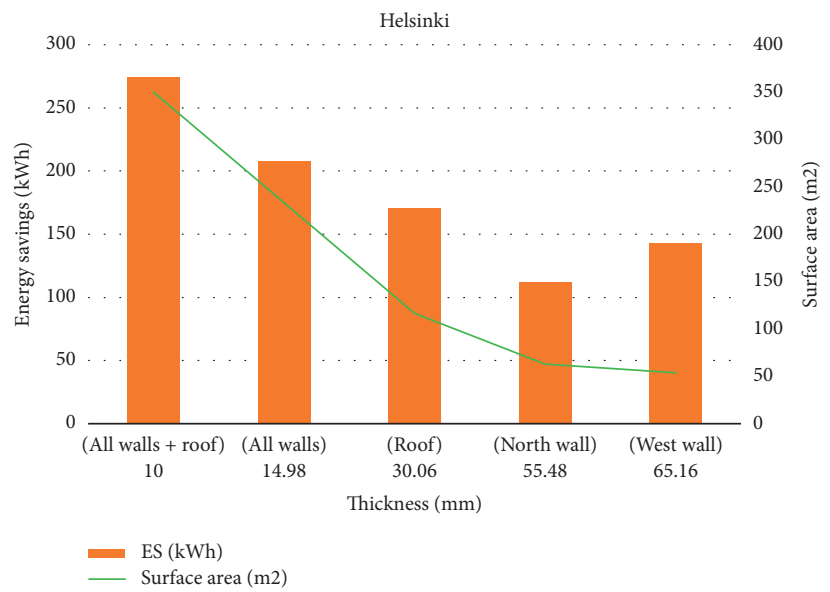

FIgURE 13: Annual energy savings in Helsinki city with different PCM surface areas and thicknesses (having constant volume).

reported by Lei et al. [40] while evaluating the energy efficiency of a cubic room model located in Singapore. It is pertinent to mention here that after $25 \mathrm{~mm}$ thick PCM layer, the drop in ECR per mm was almost constant.

In the second scenario, the volume of PCM is kept constant, and the effect of surface area and thickness are evaluated. The thickness of the PCM layer was determined by dividing the total volume of the PCM by the surface area of the place, where the PCM was applied (walls/roof). The results are provided for Helsinki city. For this purpose, the PCM, which showed the best performance (PCM26) in Helsinki city, was selected.

The results of annual energy savings with different surfaces and thicknesses are illustrated in Figure 13. In general, annual energy savings strengthened with the enlargement of the surface area of the PCM layer and reduced with thicker PCM layers. Such behaviour can be explained due to the efficient growth of the heat transfer rate between PCM and the building [29]. In comparison to thicker PCM layer, thinner PCM layers are possibly more effective during melting freezing cycles. In addition, thicker PCM layers usually require more time to complete the phase change cycle. Hence, it is believed that some part of the PCM may possibly remain in solid-state, thereby influencing the efficiency of the PCM to work to full capacity [29]. Although west wall has more thickness and less surface area than the north wall, it showed higher energy savings. The reason for such phenomena can be the fluctuation of solar radiation received by these locations [29]. Based on the above discussion, the highest energy savings for Helsinki city are obtained when PCM is applied to all walls and roof of a two-storey residential building.

\section{Conclusions}

The main conclusions obtained from this research are the following:

(i) For all eight cities, the maximum monthly energy savings in lightweight steel-framed residential building impregnated with PCM were achieved in April, May, September, and October months. The maximum energy savings during these months were up to $142 \mathrm{kWh}$. During these months, the maximum temperature in PCM-integrated buildings located in 
these cities reduced by up to $3.31^{\circ} \mathrm{C}$ proposing that part of the heating load has been taken by PCM. Also, the temperature fluctuation reduction values ranged from $0.88^{\circ} \mathrm{C}$ in Helsinki to $3.13^{\circ} \mathrm{C}$ in Moscow. This can lead to the enhancement of the indoor thermal comfort for dwellers.

(ii) The selection of optimum PCM in warm summer humid continental climate (Dfb climate region) was strongly influenced by energy savings in heating and cooling. The optimum PCM in buildings located in Kiev and Stockholm, where energy savings in heating were higher, was found to be PCM 21. For Helsinki, Saint Petersburg, Moscow, Toronto, and Montreal, the high melting temperature PCMs (24-26) were found to be optimum. In these cities, the cooling energy savings were found to be the highest. For Ottawa, where heating and cooling savings were almost similar, the mild-melting temperature PCM (PCM 23) was found to be optimum. Thus, for heating dominant cities of the $\mathrm{Dfb}$ climate zone, low melting temperature PCMs should be used since they show the highest efficiency; for cooling dominant cities, high melting temperature PCMs; and for cities with uniform heating and cooling demands, mild-melting temperature PCMs.

(iii) The annual energy savings in all eight cities ranged from 196.55 to $391.07 \mathrm{kWh}$ suggesting that the integration of PCM into building framework is an appropriate approach for boosting the energy efficiency of buildings.

(iv) For a varying volume of PCM, the energy savings and energy consumption reduction raised with the increase in the thickness of the PCM layer. For constant volume, it was revealed that the PCM efficiency enhanced with the enlargement of the surface area and the reduction in the thickness of the PCM layer. Also, higher energy efficiency in Helsinki city was obtained when PCM was applied to all walls and roof of the lightweight residential building.

(v) Conclusively, the application of PCM into lightweight steel-framed residential structure located in warm summer humid continental climate region is feasible.

\section{Data Availability}

The dataset included in the paper was supported by funding from Nazarbayev University and at this stage cannot be included.

\section{Conflicts of Interest}

The authors declare that they have no conflicts of interest.

\section{Acknowledgments}

This research was supported by Nazarbayev University Faculty development competitive research grants (090118FD5316) and ORAU Grant no. SOE2017003.

\section{References}

[1] I. E. Agency, Technology Roadmap: Energy Efficient Building Envelopes, OCED/IEA, Paris, France, 2013.

[2] I. E. Agency, Key World Energy Statistics, p. 80, International Energy Agency, Paris, France, 2012.

[3] I. E. Agency, Transition to Sustainable Buildings Strategies and Opportunities to 2050, OECD/IEA, Paris, France, 2013.

[4] L. Coppola, D. Coffetti, and S. Lorenzi, "Cement-Based renders manufactured with phase-change materials: applications and feasibility," Advances in Materials Science and Engineering, vol. 2016, p. 6, 2016.

[5] D. Foti and F. Ruggiero, Recent Advances and Applications of Seismic Isolation and Energy Dissipation Devices in Frontiers in Built, Environmental Development, London, UK, 2020.

[6] L. Navarro, A. de Gracia, S. Colclough et al., "Thermal energy storage in building integrated thermal systems: a review. Part 1. active storage systems," Renewable Energy, vol. 88, pp. 526-547, 2016.

[7] C. Fabiani, A. L. Pisello, M. Barbanera, L. F. Cabeza, and F. Cotana, "Assessing the potentiality of animal fat based-bio phase change materials (PCM) for building applications: an innovative multipurpose thermal investigation," Energies, vol. 12, no. 6, p. 1111, 2019.

[8] M. Saffari, A. de Gracia, C. Fernández, and L. F. Cabeza, "Simulation-based optimization of PCM melting temperature to improve the energy performance in buildings," Applied Energy, vol. 202, pp. 420-434, 2017.

[9] P. Marin, M. Saffari, A. de Gracia et al., "Energy savings due to the use of PCM for relocatable lightweight buildings passive heating and cooling in different weather conditions," Energy and Buildings, vol. 129, pp. 274-283, 2016.

[10] Y. Zhang, S. Zhuang, Q. Wang, and J. He, "Experimental research on the thermal performance of composite PCM hollow block walls and validation of phase transition heat transfer models," Advances in Materials Science and Engineering, vol. 2016, p. 15, 2016.

[11] S. A. Memon, "Phase change materials integrated in building walls: a state of the art review," Renewable and Sustainable Energy Reviews, vol. 31, pp. 870-906, 2014.

[12] V. Bendic and D. Dobrotă, "Theoretical and experimental contributions on the use of smart composite materials in the construction of civil buildings with low energy consumption," Energies, vol. 11, no. 9, p. 2310, 2018.

[13] M. A. Gómez, M. A. Álvarez Feijoo, R. Comesaña, P. Eguía, J. L. Míguez, and J. Porteiro, "CFD simulation of a concrete cubicle to analyze the thermal effect of phase change materials in buildings," Energies, vol. 5, no. 7, pp. 2093-2111, 2012.

[14] S. Ying Kong, X. Yang, S. Chandra Paul, L. Sing Wong, and B. Š ng W, "Thermal response of mortar panels with different forms of macro-encapsulated phase change materials: a finite element study," Energies, vol. 12, no. 13, p. 2636, 2019.

[15] A. V. Sa, R. M. S. F. Almeida, H. Sousa, and J. M. P. Q. Delgado, "Numerical analysis of the energy improvement of plastering mortars with phase change materials," Advances in Materials Science and Engineering, vol. 2014, p. 12, 2014.

[16] M. Vautherot, F. Maréchal, and M. M. Farid, "Analysis of energy requirements versus comfort levels for the integration of phase change materials in buildings," Journal of Building Engineering, vol. 1, pp. 53-62, 2015.

[17] L. Pajek, B. Hudobivnik, R. Kunič, and M. Košir, "Improving thermal response of lightweight timber building envelopes during cooling season in three European locations," Journal of Cleaner Production, vol. 156, pp. 939-952, 2017. 
[18] X. Mi, R. Liu, H. Cui, S. A. Memon, F. Xing, and Y. Lo, "Energy and economic analysis of building integrated with PCM in different cities of China," Applied Energy, vol. 175, pp. 324-336, 2016.

[19] S. Ramakrishnan, X. Wang, J. Sanjayan, and J. Wilson, "Thermal performance of buildings integrated with phase change materials to reduce heat stress risks during extreme heatwave events," Applied Energy, vol. 194, pp. 410-421, 2017.

[20] F. Ascione, N. Bianco, R. F. De Masi, F. de' Rossi, and G. P. Vanoli, "Energy refurbishment of existing buildings through the use of phase change materials: energy savings and indoor comfort in the cooling season," Applied Energy, vol. 113, pp. 990-1007, 2014.

[21] N. Soares, A. R. Gaspar, P. Santos, and J. J. Costa, "Multidimensional optimization of the incorporation of PCMdrywalls in lightweight steel-framed residential buildings in different climates," Energy and Buildings, vol. 70, pp. 411-421, 2014.

[22] B. Nghana and F. Tariku, "Phase change material's (PCM) impacts on the energy performance and thermal comfort of buildings in a mild climate," Building and Environment, vol. 99, pp. 221-238, 2016.

[23] D. Chen and H. W. Chen, "Using the Köppen classification to quantify climate variation and change: an example for 19012010," Environmental Development, vol. 6, pp. 69-79, 2013.

[24] M. Kottek, J. Grieser, C. Beck, B. Rudolf, and F. Rubel, "World Map of the Köppen-Geiger climate classification updated," Meteorologische Zeitschrift, vol. 15, no. 3, pp. 259-263, 2006.

[25] Humid Continental (Group D), Physical Geography, 2020, https://courses.lumenlearning.com/geophysical/chapter/hum id-continental-group-d/.

[26] M. C. Peel, B. L. Finlayson, and T. A. McMahon, "Updated world map of the Köppen-Geiger climate classification," Hydrology and Earth System Sciences, vol. 11, no. 5, pp. 1633-1644, 2007.

[27] C. O. Pedersen, "Advanced zone simulation in EnergyPlus: incorporation of variable properties and phase change material (PCM) capability," in Proceedings of the Building Simulation, Beijing, China, 2007.

[28] P. C. Tabares-Velasco, C. Christensen, and M. Bianchi, "Verification and validation of EnergyPlus phase change material model for opaque wall assemblies," Building and Environment, vol. 54, pp. 186-196, 2012.

[29] M. Alam, H. Jamil, J. Sanjayan, and J. Wilson, “Energy saving potential of phase change materials in major Australian cities," Energy and Buildings, vol. 78, pp. 192-201, 2014.

[30] S. Ramakrishnan, X. Wang, J. Sanjayan, and J. Wilson, "Thermal performance assessment of phase change material integrated cementitious composites in buildings: experimental and numerical approach," Applied Energy, vol. 207, pp. 654-664, 2017.

[31] M. Saffari, A. de Gracia, S. Ushak, and L. F. Cabeza, "Economic impact of integrating PCM as passive system in buildings using Fanger comfort model," Energy and Buildings, vol. 112, pp. 159-172, 2016.

[32] S. Werner, "International review of district heating and cooling," Energy, vol. 137, pp. 617-631, 2017.

[33] BSI, "Indoor environmental input parameters for design and assessment of energy performance of buildings- addressing indoor air quality, thermal environment, lighting and acoustics contents," BSI, London, UK, 2007.

[34] H. Cui, S. A. Memon, and R. Liu, "Development, mechanical properties and numerical simulation of macro encapsulated thermal energy storage concrete," Energy and Buildings, vol. 96, pp. 162-174, 2015.

[35] F. Kuznik and J. Virgone, "Experimental assessment of a phase change material for wall building use," Applied Energy, vol. 86, no. 10, pp. 2038-2046, 2009.

[36] L. Shilei, Z. Neng, and F. Guohui, "Impact of phase change wall room on indoor thermal environment in winter," Energy and Buildings, vol. 38, no. 1, pp. 18-24, 2006.

[37] P. Schossig, H. Henning, S. Gschwander, and T. Haussmann, "Micro-encapsulated phase-change materials integrated into construction materials," Solar Energy Materials and Solar Cells, vol. 89, no. 2-3, pp. 297-306, 2005.

[38] S. A. Memon, H. Z. Cui, H. Zhang, and F. Xing, "Utilization of macro encapsulated phase change materials for the development of thermal energy storage and structural lightweight aggregate concrete," Applied Energy, vol. 139, pp. 43-55, 2015.

[39] F. Souayfane, P. H. Biwole, and F. Fardoun, "Thermal behavior of a translucent superinsulated latent heat energy storage wall in summertime," Applied Energy, vol. 217, pp. 390-408, 2018.

[40] J. Lei, J. Yang, and E.-H. Yang, "Energy performance of building envelopes integrated with phase change materials for cooling load reduction in tropical Singapore," Applied Energy, vol. 162, pp. 207-217, 2016. 